\title{
Multi-criteria evaluation of renewable energy alternatives for electricity generation in a residential building.
}

SEDDIKI, M. and BENNADJI, A.

2019 


\section{Multi-criteria evaluation of renewable energy alternatives for}

\section{2 electricity generation in a residential building}

3 Abstract

4 The residential sector is well known to be one of the main energy consumers worldwide. The

5 purpose of this study is to select the best renewable energy alternatives for electricity generation

6 in a residential building by using a new integrated fuzzy multi-criteria group decision-making

7 method. In renewable energy decision-making problems, the preferences of experts and

8 decision-makers are generally uncertain. Furthermore, it is challenging to quantify the reel

9 performance of renewable energy alternatives using a set of exact values. Fuzzy logic is commonly applied to deal with those uncertainties.

The method proposed in this paper combines different methods. First, the Delphi method is used in order to select a preliminary set of renewable energy alternatives for electricity generation as well as a preliminary set of criteria (economic, environmental, social, etc.). Then, the questionnaire is used to study the renewable energy alternatives preferences of the residents of the residential building'. Later, the FAHP (Fuzzy Analytical Hierarchy Process) is implemented to obtain the weighs of the criteria taking into consideration uncertainties in expert's judgments. Finally, the FPROMETHEE (Fuzzy Preference Ranking Organization Method for Enrichment Evaluation) global ranking is performed in order to get a complete ranking of the renewable energy alternatives taking into account uncertainties related to the alternatives’ evaluations.

The originality of this paper comes from the application of the proposed integrated DelphiFAHP- FPROMETHEE methodology for the selection of the best renewable energy 
23 alternatives for electricity generation in a residential building. A case study has validated the

24 effectiveness and the applicability of the proposed method. The results reveal that the proposed integrated method helps to formulate the problem and is particularly effective in handling uncertain data. It facilitates the selection of the best renewable energy alternatives in a manner that is participatory, comprehensive, robust, and reliable.

\section{Keywords:}

Delphi, FAHP, FPROMETHEE, residential buildings, electricity generation, renewable energy alternatives

(1)

3

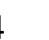

35

(1)




\section{Introduction}

It is no longer debated that the world energy consumption and $\mathrm{CO}_{2}$ emissions are directly affecting the climate change and the global warming. In order to preserve the planet for the future generations, the reduction in energy consumption and $\mathrm{CO}_{2}$ emissions is of crucial importance. The residential energy sector has become strategic to achieve rapid $\mathrm{CO}_{2}$ emission reductions. In fact, $25 \%$ of the global energy is consumed by the residential sector while he is responsible of $17 \%$ of the global $\mathrm{CO}_{2}$ emissions (6\% of direct and $11 \%$ of indirect due to electricity consumption) [1]. Consequently, the control of $\mathrm{CO}_{2}$ emissions in the residential sector would positively affect the climate change and the global warming.

Electricity represents a very important energy source for the global residential sector. It is the second largest energy source for global residential needs accounting for $21 \%$ of energy utilization preceded only by traditional biomass, which represents $40 \%$ of the total residential energy market [2]. It is clear that the rise in energy consumption in the global residential sector is directly increasing the global warming. However, the global warming is affecting the energy consumption in the global residential sector as well. In fact, the residential cooling depends on the exterior climate and the expansion, persistence, and intensification of heat waves caused by the global warming is rising the electricity demands for the cooling needs [3].

For the developing as well as the developed countries, energy production is a very important factor in order to reach their development objectives and to support their growing economy, urbanization, and population. In order to highlight the importance of sustainable development and green energy, the decade 2014-2024 was declared unanimously as "the Decade of Sustainable Energy for All” by The United Nations General Assembly [4].

Renewable energy support policies of different countries (China, EU members US, Canada, Australia, etc.) have been introduced essentially to convert the current energy systems 
(increased use of fossil fuels, increased energy consumption and significant emissions of environmental pollutants) to highly efficient green sustainable energy systems. Currently, 164 countries (more than a half are developing countries) have sustainable energy development as a target and 145 countries have already in place policies to support their sustainable energy development [5].

In order to deal with the environmental concerns coming in the path of sustainable development, the integration of appropriate renewable energy alternatives for electricity generation in residential buildings is of crucial importance. For instance, since 2014 the use of minimum levels of energy from renewable sources in new buildings and in existing buildings that are subject to major renovation is required by the building regulations of EU member states [6]. However, different drivers and barriers influence the expansion of electricity generation from renewable energy sources (techno-economic, administrative, political and social barriers) [79].

Many scholars have considered the lack of methodological support in order to select the best renewable energy alternative as the main barrier to the implementation of electricity generation from renewable energy sources. Numerous studies concerning the selection of the best renewable energy alternative are available for Romania [10], Malaysia [11], Turkey [12], Lithuania [13], Saudi Arabia [14], Greece [15], and Ecuador [16]. These studies highlighted the fact that the selection of the best solutions among a vast diversity of alternatives (wind generators, biomass, solar energy, geothermal, hydro generators) taking into consideration different criteria (economic, environmental, social, etc.) is a complex decision problem.

Other studies conducted in Finland [17], United Kingdom [18], Lithuania [19], and Greece [20] have emphasized on the necessity to take into account the renewable energy alternatives preferences of the inhabitants of the residential buildings. 
Another stream of research has focused on different uncertainties that can affect the evaluation of renewable energy alternatives [21]. Numerous studies have highlighted the fact that it is difficult to quantify the reel performance of renewable energy alternatives using a set of exact values since the judgments of experts, residents, and decision makers are generally uncertain. For example, Kaya and Kahraman [12] have selected the best renewable energy alternative for Istanbul (Turkey) taking into account the vagueness's in decision makers' judgments. Similar studies concerning the uncertainties that can affect the evaluation of renewable energy alternatives are available for Jordan [22], Indonesia [23], China [24], and Canada [25].

The multiple-criteria decision analysis is an operational evaluation that is very useful for addressing complex problems involving different alternatives, criteria, stakeholders and high uncertainty [26]. To overcome the uncertainties that can affect the evaluation of renewable energy alternatives, fuzzy numbers are commonly combined with multiple criteria decisionmaking as a way to help linguistic variables be expressed appropriately [27].

The originality of this paper comes from the application of a new fuzzy integrated DelphiFAHP- FPROMETHEE methodology for the selection of the best renewable energy alternatives for electricity generation in a residential building.

This paper is divided into 6 sections: the next section presents a literature review concerning the application of multi-criteria decision aid methods for the evaluation of renewable energy alternatives, section 3 develops the new fuzzy integrated Delphi- FAHP- FPROMETHEE method used in this paper, section 4 provides the results of the application of the proposed method on a case study, section 5 presents a discussion, while section 6 presents conclusions and directions for future research. 


\section{Literature review}

119 Table 1 presents the multi-criteria decision-making methods that were used for the evaluation of renewable energy alternatives for electricity generation highlighting, the objective of the evaluation, the method used, the scale of application, and the scientific journal in which the research was published.

As indicated in table 1, Multi-Criteria Decision Analysis (MCDA) methods were widely applied for the evaluation of renewable energy alternatives for electricity generation. However, the application of MCDA methods is almost at a global, national, or regional scale [10-16, 28, 30-36]. Actually, there are limited uses of MCDA methods for the evaluation of renewable energy alternatives for electricity generation at the scale of a single residential building [17, 3739]. The evaluation of renewable energy alternatives for electricity generation for a single residential building is a relatively new area of application for MCDA methods. Moreover, to the best knowledge of the authors, none of the current methods takes into account at the same times the following aspects:

- The application of Delphi method with experts and decision makers as well as questionnaires with residents in order to identify the most relevant criteria as well as renewable energy alternatives on a participatory base.

- The implementation of FAHP method in order to determinate criteria weights taking into account the uncertainties in the judgments of experts and decision-makers.

- The application of FPROMETHEE method in order to select the best renewable energy alternative taking into account different evaluation criteria as well as vagueness and approximations in the evaluations of the alternatives.

This paper suggests a new fuzzy integrated Delphi- FAHP-FPROMETHEE decision aid method for the evaluation of renewable energy alternatives for electricity generation for a single residential building. Suganthi et al. [21] have provided a large literature review about the 
residential building.

147 Table 1: Main scientific works available in the literature concerning MCDA applications in the evaluation of renewable energy alternatives for electricity generation

\begin{tabular}{|c|c|c|c|c|}
\hline Authors & Objectives of the evaluation & MCDA methods & $\begin{array}{l}\text { Scales of } \\
\text { application }\end{array}$ & Journals \\
\hline Maxim [10] & $\begin{array}{l}\text { To rank electricity generation } \\
\text { alternatives focusing on their } \\
\text { compatibility with the sustainable } \\
\text { development of the industry. }\end{array}$ & $\begin{array}{l}\text { Weighted sum multi- } \\
\text { attribute utility method }\end{array}$ & Global scale & Energy Policy \\
\hline $\begin{array}{l}\text { Ahmed and } \\
\text { Tahar [11] }\end{array}$ & $\begin{array}{l}\text { Selection of renewable energy } \\
\text { sources for the sustainable } \\
\text { development of electricity generation } \\
\text { in Malaysia }\end{array}$ & AHP & National scale & $\begin{array}{l}\text { Renewable } \\
\text { Energy }\end{array}$ \\
\hline $\begin{array}{l}\text { Palmas et al. } \\
\text { [28] }\end{array}$ & $\begin{array}{l}\text { Find the best locations for new } \\
\text { residential areas developments, which } \\
\text { use micro-renewable technologies. }\end{array}$ & GIS-AHP & Regional scale & $\begin{array}{l}\text { Energy, } \\
\text { Sustainability and } \\
\text { Society }\end{array}$ \\
\hline $\begin{array}{l}\text { Önüt et } \\
\text { al.[29] }\end{array}$ & $\begin{array}{l}\text { To evaluate the most suitable energy } \\
\text { resources for the manufacturing } \\
\text { industry in Turkey. }\end{array}$ & ANP & National scale & $\begin{array}{l}\text { Energy } \\
\text { Conversion and } \\
\text { Management }\end{array}$ \\
\hline $\begin{array}{l}\text { Kaya et al. } \\
{[12]}\end{array}$ & $\begin{array}{l}\text { The selection of the best renewable } \\
\text { energy alternative for Istanbul. }\end{array}$ & Fuzzy VIKOR-AHP & Regional scale & Energy \\
\hline $\begin{array}{l}\text { Štreimikienè } \\
\text { et al. [13] }\end{array}$ & $\begin{array}{l}\text { The selection of electricity } \\
\text { generation technologies in Lithuania }\end{array}$ & AHP -ARAS & National scale & $\begin{array}{l}\text { Renewable } \\
\text { Energy }\end{array}$ \\
\hline $\begin{array}{l}\text { Al Garni el } \\
\text { al. [14] }\end{array}$ & $\begin{array}{l}\text { The evaluation of renewable energy } \\
\text { alternatives for electricity generation } \\
\text { in Saudi Arabia }\end{array}$ & AHP & National scale & $\begin{array}{l}\text { Sustainable } \\
\text { Energy } \\
\text { Technologies and } \\
\text { Assessments }\end{array}$ \\
\hline $\begin{array}{l}\text { Diakoulaki } \\
\text { and } \\
\text { Karangelis } \\
\text { [15] }\end{array}$ & $\begin{array}{l}\text { The evaluation of renewable energy } \\
\text { alternatives for power generation } \\
\text { sector in Greece }\end{array}$ & PROMETHEE & National scale & $\begin{array}{l}\text { Renewable and } \\
\text { Sustainable } \\
\text { Energy Reviews }\end{array}$ \\
\hline $\begin{array}{l}\text { Barragán et } \\
\text { al. [16] }\end{array}$ & $\begin{array}{l}\text { The evaluation of renewable energy } \\
\text { technologies for electricity } \\
\text { generation in the city of Cuenca, } \\
\text { Ecuador }\end{array}$ & PROMETHEE & Regional scale & $\begin{array}{l}\text { Renewable } \\
\text { Energies and } \\
\text { Power Quality } \\
\text { journal }\end{array}$ \\
\hline $\begin{array}{l}\text { Talukdar et } \\
\text { al. [30] }\end{array}$ & $\begin{array}{l}\text { The evaluation of photovoltaic (PV) } \\
\text { panel alternatives for Grid-tie PV } \\
\text { electricity generation system in } \\
\text { Dhaka, Bangladesh }\end{array}$ & TOPSIS & Regional scale & $\begin{array}{l}\text { International } \\
\text { Journal of } \\
\text { Innovative } \\
\text { Research in }\end{array}$ \\
\hline
\end{tabular}




\begin{tabular}{|c|c|c|c|c|}
\hline & & & & $\begin{array}{l}\text { Electrical, } \\
\text { Electronics, } \\
\text { Instrumentation } \\
\text { and Control } \\
\text { Engineering }\end{array}$ \\
\hline $\begin{array}{l}\text { Strantzali et } \\
\text { al. [31] }\end{array}$ & $\begin{array}{l}\text { The evaluation of the best } \\
\text { combination of a fuel with renewable } \\
\text { energy alternatives for electricity } \\
\text { generation in an isolated Greek } \\
\text { island, Lesvos }\end{array}$ & PROMETHEE & Regional scale & $\begin{array}{l}\text { Renewable and } \\
\text { Sustainable } \\
\text { Energy Reviews }\end{array}$ \\
\hline $\begin{array}{l}\text { Çelikbilek et } \\
\text { al.[32] }\end{array}$ & $\begin{array}{l}\text { The evaluation of renewable energy } \\
\text { sources for power generation at a } \\
\text { national level }\end{array}$ & $\begin{array}{l}\text { Grey systems } \\
\text { ANP } \\
\text { DEMATEL } \\
\text { VIKOR }\end{array}$ & National scale & Energy \\
\hline $\begin{array}{l}\text { Kausika et } \\
\text { al. [33] }\end{array}$ & $\begin{array}{l}\text { The determination of the residential } \\
\text { solar photovoltaic potential of the } \\
\text { city of Apeldoorn in the Netherlands }\end{array}$ & GIS-AHP & Postal code area & Energy Procedia \\
\hline $\begin{array}{l}\text { Jung et al. } \\
\text { [34] }\end{array}$ & $\begin{array}{l}\text { The identification of public } \\
\text { perceptions of renewable energy } \\
\text { systems for power generation in } \\
\text { Helsinki, Finland. }\end{array}$ & SMAA & Regional scale & $\begin{array}{l}\text { Renewable } \\
\text { Energy }\end{array}$ \\
\hline $\begin{array}{l}\text { Rojas-Zerpa, } \\
\text { and Yusta } \\
\text { [35] }\end{array}$ & $\begin{array}{l}\text { The determination of the best } \\
\text { electricity supply alternatives for } \\
\text { rural areas }\end{array}$ & AHP-VIKOR & Regional scale & $\begin{array}{l}\text { Renewable and } \\
\text { Sustainable } \\
\text { Energy Reviews }\end{array}$ \\
\hline $\begin{array}{l}\text { Yunna et } \\
\text { al.[36] }\end{array}$ & $\begin{array}{l}\text { Social sustainability assessment of } \\
\text { the best hydropower alternative for } \\
\text { remote areas }\end{array}$ & $\begin{array}{l}\text { PROMETHEE- } \\
\text { HFLTS-ANP }\end{array}$ & Regional scale & $\begin{array}{l}\text { Sustainable Cities } \\
\text { and Society }\end{array}$ \\
\hline $\begin{array}{l}\text { Kontu et } \\
\text { al.[17] }\end{array}$ & $\begin{array}{l}\text { The selection of the best heating } \\
\text { systems for a new sustainable } \\
\text { residential area. }\end{array}$ & SMAA & $\begin{array}{l}\text { Single } \\
\text { residential } \\
\text { building }\end{array}$ & $\begin{array}{l}\text { Energy and } \\
\text { Buildings }\end{array}$ \\
\hline $\begin{array}{l}\text { Yuehong et } \\
\text { al. [37] }\end{array}$ & $\begin{array}{l}\text { The design optimization of the } \\
\text { renewable energy system sizes in } \\
\text { low/zero energy buildings. }\end{array}$ & $\begin{array}{l}\text { Single objective } \\
\text { optimization using } \\
\text { Genetic Algorithm } \\
\text { Multi-objectives } \\
\text { optimization using } \\
\text { NSGA-II }\end{array}$ & $\begin{array}{l}\text { Single } \\
\text { residential } \\
\text { building }\end{array}$ & $\begin{array}{l}\text { Energy and } \\
\text { Buildings }\end{array}$ \\
\hline $\begin{array}{l}\text { Catalina et } \\
\text { al.[38] }\end{array}$ & $\begin{array}{l}\text { The selection of the best combination } \\
\text { of renewable energy systems for } \\
\text { residential buildings. }\end{array}$ & ELECTRE III & $\begin{array}{l}\text { Single } \\
\text { residential } \\
\text { building }\end{array}$ & $\begin{array}{l}\text { Renewable } \\
\text { Energy }\end{array}$ \\
\hline $\begin{array}{l}\text { Ren el } \\
\text { al.[39] }\end{array}$ & $\begin{array}{l}\text { The evaluation of the optimal } \\
\text { residential energy systems in Japan }\end{array}$ & AHP-PROMETHEE & $\begin{array}{l}\text { Single } \\
\text { residential } \\
\text { building }\end{array}$ & Energy Policy \\
\hline
\end{tabular}


MCDA: Multi-Criteria Decision Aid; AHP: Analytical Hierarchy Process; GIS: Geographic Information System; ANP: Analytic network process; VIKOR: VlseKriterijuska Optimizacija I Komoromisno Resenje; ARAS :Additive Ratio Assessment method; PROMETHEE: Preference Ranking Organization Method for Enrichment Evaluation; TOPSIS: Technique for Order of Preference by Similarity to Ideal Solution; DEMATEL: Decision Making Trial and Evaluation Laboratory; SMAA: Stochastic Multi-criteria Acceptability Analysis; NSGA-II :Non-dominated Sorting Genetic Algorithm; ELECTRE: Elimination and Choice Expressing the Reality; HFLTS:Hesitant Fuzzy Linguistic Term Set

\section{A fuzzy integrated Delphi- FAHP- FPROMETHEE methodology}

This section introduces Delphi, FAHP, FPROMETHEE methods, and the new fuzzy integrated Delphi-FAHP-FPROMETHEE approach proposed in this paper.

\subsection{Delphi}

The Delphi method is an organised and collaborating method, which depend on a group of anonymous experts [26]. Delphi is an appropriate method to reach a consensus of judgments concerning a problem not subject to an objective solution [40]. Through multiple rounds of data collections, the participants share opinions, expertise, and information until a consensus is obtained [41]. A comprehensive review of Delphi method applications has been presented by Keeney et al. [42]. The Delphi method used in this paper consists of different steps: first, a group of experts should be formed. Secondly, each expert is requested independently to express his evaluation criteria, considering the different sides of the problem such as economic, environmental, societal, etc. Later, the separate lists are united into a comprehensive list, which is presented to all the experts. The participants are asked to examine this data and to review their original separate list. Finally, the process is stopped when the experts reach a consensus [40]. The Delphi method is also useful to define the renewable energy alternatives.

\subsection{FAHP}

The FAHP (Fuzzy Analytic Hierarchy Process) method represents the association between the AHP method and the fuzzy numbers. The AHP method was developed by Saaty [43]. According 
to Macharis et al. [44], the AHP method is based on three main principles: (1) construction of

178 a hierarchy with goals into different levels, (2) using a nine-point scale, pair-wise comparisons

179 for each level with respect to the goal of the best alternative selection are conducted, and (3)

180 logical consistency. This procedure is explained in detail in Saaty [43]. According to Kabir and

181 Sumi [45], the application of the AHP method has different limitations as follow: (1) the AHP

182 method is generally used to solve problems using crisp numbers, (2) the pair-wise comparison

183 of the AHP method does not take into account uncertainties concerning the humans' opinions,

(3) the opinions of the decision makers have a significant impact on the AHP outcomes since

the AHP method uses the complete aggregation approach. Numerous researchers have integrated fuzzy theory with AHP method in order to deal with issues of uncertainties [46]. The main point of the fuzzy set theory is that a membership function defines the membership degree of an element in a fuzzy set [47]. A fuzzy set contains elements that have different degrees of membership in it, the most frequently used range for indicating the degree of membership function is the unit interval $(0,1)$ [48]. Different types of fuzzy membership functions have been proposed in the literature, Van Laarhoven and Pedrycz [49] proposed triangular fuzzy numbers, Buckley el. [50] suggested trapezoidal fuzzy numbers, Chang [51] proposed the extent analysis method for handling FAHP using Triangular Fuzzy Numbers (TFN) for the pairwise comparison scale of FAHP. In order to deal with uncertain judgments in a fuzzy environment, triangular fuzzy numbers are used in this paper due to the simplicity of their calculations. As indicated in Taha and Rostam [48] a fuzzy number Ã on R is a triangular fuzzy 197 number $(\mathrm{l}, \mathrm{m}, \mathrm{u})$ if it is membership function $\mathrm{x} \in \tilde{\mathrm{A}}, \mu_{\tilde{\mathrm{A}}}(x): \mathrm{R} \rightarrow[0,1]$ is equal to as follows 198 (see figure 1) :

$$
\mu_{\tilde{\AA}}(x)=\left\{\begin{array}{cr}
(x-l) /(m-l) & l \leq \mathrm{x} \leq \mathrm{m} \\
(u-x) /(u-m) & m \leq \mathrm{x} \leq \mathrm{u} \\
0 & \text { otherwise }
\end{array}\right.
$$


199 Where, the parameters $l, m$ and $u$ respectively express the smallest values, the most possible 200 value, and the largest possible value.

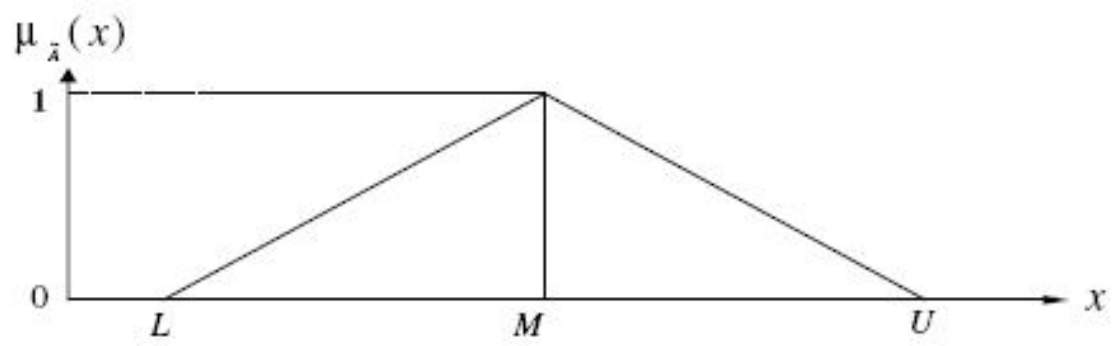

Figure 1: The membership function of the triangular fuzzy number [52]

The different steps of the fuzzy-AHP process used in this paper are explained below as indicated in Gupta et al [53] and Seddiki et al. [52]:

Step 1 Pairwise comparisons of the criteria: First, each expert has to perform a pairwise comparison of the criteria taking into consideration the global objective (in this paper the global objective is the selection of the best renewable energy alternative for electricity generation in a 209 residential building). These comparisons allow evaluating the criteria weights using a fuzzy 210 linguistic (qualitative) scale (see figure 2). The vagueness in the expert judgments are taken 211 into account through the linguistic scale. This information is converted to fuzzy triangular 212 numbers (l, m, u) as indicated in table 2. 


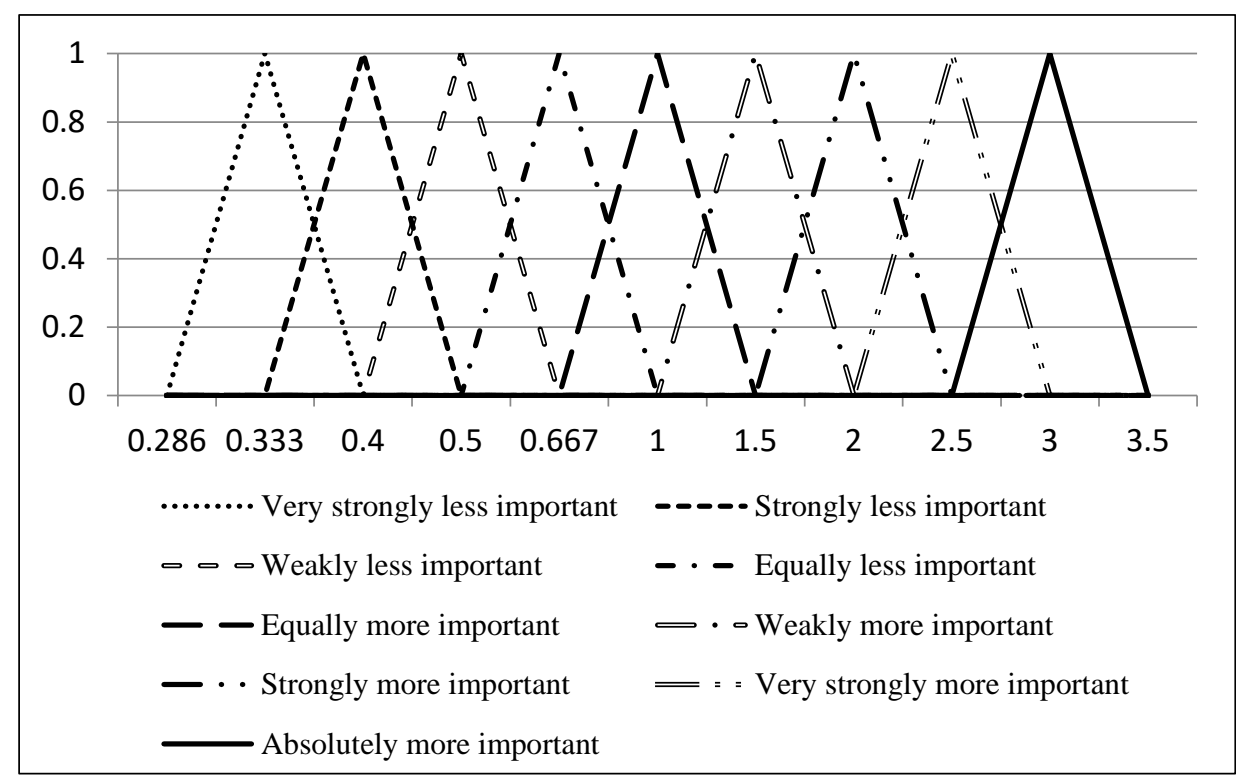

Figure 2: Linguistic scale of the criteria weight [54]

Table 2 : Triangular fuzzy conversion scale [53]

\begin{tabular}{llll}
\hline Linguistic scale & $\begin{array}{l}\text { Triangular } \\
\text { fuzzy scale }\end{array}$ & $\begin{array}{l}\text { Reciprocal } \\
\text { linguistic scale }\end{array}$ & $\begin{array}{l}\text { Triangular fuzzy } \\
\text { reciprocal scale }\end{array}$ \\
\hline Just equal ( JE) & $(1,1,1)$ & Just equal ( JE) & $(1,1,1)$ \\
$\begin{array}{l}\text { Equally more } \\
\text { important (EMI) }\end{array}$ & $(0.5,1,1.5)$ & $\begin{array}{l}\text { Equally less } \\
\text { important (ELI) }\end{array}$ & $(0.667,1,2)$ \\
$\begin{array}{l}\text { Weakly more } \\
\text { important (WMI) }\end{array}$ & $(1,1.5,2)$ & $\begin{array}{l}\text { Weakly less } \\
\text { important (WLI) }\end{array}$ & $(0.5,0.667,1)$ \\
$\begin{array}{l}\text { Strongly more } \\
\text { important (SMI) }\end{array}$ & $(1.5,2,2.5)$ & $\begin{array}{l}\text { Strongly less } \\
\text { important (SLI) }\end{array}$ & $(0.4,0.667,1)$ \\
$\begin{array}{l}\text { Very strongly } \\
\text { more important }\end{array}$ & $(2,2.5,3)$ & $\begin{array}{l}\text { Very strongly less } \\
\text { impsintant }\end{array}$ & $(0.333,0.4,0.5)$ \\
$\begin{array}{l}\text { Absolutely more } \\
\text { important (AMI) }\end{array}$ & $(2.5,3,3.5)$ & $\begin{array}{l}\text { (VSLI) } \\
\text { Absolutely less } \\
\text { important(ALI) }\end{array}$ & $(0.286,0.33,0.4)$ \\
\hline
\end{tabular}

The pairwise comparison matrix for each expert is obtained as shown in equation (2).

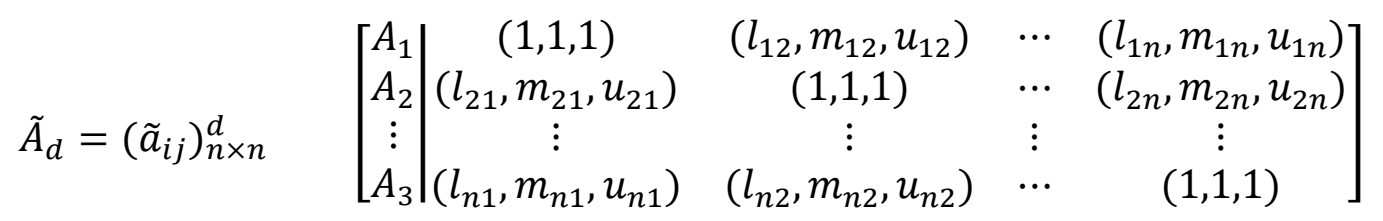

218 Where $\tilde{a}_{i j}$ is the relative importance of $i^{\text {th }}$ criterion over $j^{\text {th }}$ criterion as assigned by $d^{\text {th }}$ expert.

219 Where $d=1,2$, , D and " $\mathrm{D}$ " is the number of total the experts. 
Step 2 Obtaining the weighted comparison matrices: The weighted comparison matrix for all

experts is defined as per the following equations:

$$
\left.\widetilde{(b}_{i j}\right)_{n \times n}=\left(l_{i j}, m, u_{i j}\right)=\sum_{d=1}^{d=D} w_{d} \times\left(\tilde{a}_{i j}\right)_{n \times n}^{d} \text { for } i \leq j
$$

222

223

224

228 Where $\tilde{S}_{\text {ri }}$ is the sum of $i^{\text {th }}$ row.

229 Step 4 Find the sum of all the rows as per the following equation:

$$
\tilde{S}_{t}=\sum_{i=1}^{i=n} \tilde{S}_{r i}
$$

For $i \leq j$ and $w_{d}=$ individual weight of the $d^{\text {th }}$ expert and:

$$
\left.\left.\widetilde{(b}_{i j}\right)_{n \times n}=\widetilde{(b}_{j i}\right)_{n \times n}^{-1}=\left(\frac{1}{u_{j i}}, \frac{1}{m_{j i}}, \frac{1}{l_{j i}}\right) \text { for } i>j
$$

Step 3 Find the sum of each row of the fuzzy comparison matrix by fuzzy arithmetic operations as shown in equation 5:

$$
\tilde{S}_{r i}=\sum_{j=1}^{j=n} \tilde{b}_{i j}=\left(\sum_{j=1}^{j=n} \tilde{l}_{i j}, \sum_{j=1}^{j=n} \tilde{m}_{i j}, \sum_{j=1}^{j=n} \tilde{u}_{i j}\right)
$$

230 Step 5 Divide the sum of each row by the sum total of all the rows as per the following equation:

$$
\tilde{S}_{t}=\tilde{S}_{r i} \times\left[\tilde{S}_{t}\right]^{-1}
$$

231 To obtain the estimates for the vectors of weights under each criterion, it is required to determine the

232 degree of possibility of greatest or least fuzzy number among the several fuzzy synthetic extents.

233 Step 6 Compute the degree of possibility of $\tilde{S}_{i} \geq \tilde{S}_{j}$ by the following equation:

$$
V\left(\tilde{S}_{i} \geq \tilde{S}_{j}\right)= \begin{cases}1 & \text { if } m_{i} \geq m_{j} \\ \frac{u_{i}-l_{j}}{\left(u_{i}-m_{i}\right)+\left(m_{j}-l_{j}\right)} & \text { if } l_{j} \leq u_{i} i, j=1, \ldots, n ; j \neq i \\ 0 & \text { others }\end{cases}
$$


Step 7 Computing degree of possibility: The degree of possibility of $\tilde{S}_{i}$ over all other (n - 1) fuzzy numbers is calculated through equation 9:

$$
\begin{aligned}
V\left(\tilde{s}_{i} \geq \tilde{s}_{j} \mid j, \ldots . n ; j \neq i\right) & =\min V\left(\tilde{s}_{i} \geq \tilde{s}_{j}\right), \quad i=1, \ldots, n \\
\text { If } d^{\prime}\left(A_{i},\right) & =\min V\left(\tilde{s}_{i} \geq \tilde{s}_{j}\right)
\end{aligned}
$$

Then for $j=1, \ldots, n ; j \neq i$, the weight vector is given by equation 10 :

$$
W^{\prime}=\left(d^{\prime}\left(A_{1},\right),\left(d^{\prime}\left(A_{2},\right), \ldots,\left(d^{\prime}\left(A_{n},\right)\right)^{T}\right.\right.
$$

Normalizing the weight vector, we get the weights of the criteria as indicated in equation 11:

$$
W=\left(d\left(A_{1},\right),\left(d\left(A_{2},\right), \ldots,\left(d\left(A_{n},\right)\right)^{T}\right.\right.
$$

Where $W$ and $W^{\prime}$ are non-fuzzy numbers and are the weights of the criteria.

\subsection{FPROMETHEE}

The FPROMETHEE (Fuzzy Preference Ranking Organization METHod for Enrichment Evaluation) method is an association of fuzzy set theory with the PROMETHEE method [55]. The PROMETHEE method is a relatively simple outranking method to deal with MCDM problems. This method was developed first by Brans [56] in the form of partial ranking of alternatives (PROMETHEE I). Later different extensions of PROMETHEE methods were developed, the complete ranking PROMETHEE II, the GAIA analysis (Graphical Analysis for Interactive Aid) [57], PROMETHEE V (Optimization under constraints) [58], and the group decision support system PROMETHEE GDSS [59]. PROMETHEE methods have been successfully implemented to solve multi-criteria and multi- decision maker problems in various areas [60].

PROMETHEE method is based on the pairwise comparisons of the actions, it evaluates under specific conditions if one of two actions clearly outrank the other or not. An evaluation table that indicates the assessments of each action in terms of each criterion is essential as the first base to implement PROMETHEE method. 
PROMETHEE methods present the advantage to using the partial aggregation. Consequently, the judgments of the decision makers have a partial impact on PROMETHEE results. In fact, very bad scores on some criteria cannot be compensated with good scores in other criteria [40]. Nevertheless, PROMETHEE methods do not offer the possibility to take into account the fuzziness concerning the evaluation of the alternatives. In addition, PROMETHEE methods do not describe how to determinate the weights of the criteria in a fuzzy environment [52].

The association of PROMETHEE method with fuzzy set theory offer the possibility to take into consideration the fuzziness concerning the evaluation of alternatives regarding different criteria. FPROMETHEE has been used to solve different MCDM problems [55, 61-67].

The Fuzzy-PROMETHEE method as indicated by Gupta et al [53] was implemented in this paper because of the fuzzy nature of the decision problem. In order to deal with the uncertainties concerning the assessments of alternatives, the method proposed by Gupta et al [53] suggests that the experts should convert the results of the evaluation table that indicates the assessments of each alternative for each criterion from crisp numbers into a fuzzy linguistic scale.

According to PROMETHEE theory, weights, and preference functions have to be defined in order to apply PROMETHEE methods. Weights represent the relative importance of the criteria for decision makers. In order to deal with uncertain judgments while defining the criteria weights, FAHP is used in this paper as PROMETHEE methods do not describe how to determinate the weights of the criteria in a fuzzy environment.

Preference functions $P_{j}(a, b)$ converts the deviation between the assessments of two actions (a and b) on a specific criterion (gj) into a preference degree ranging from 0 to 1 . The preference function type IV (Level criterion) is used in this research, as it is the most appropriate preference 
278 function for fuzzy environments [68]. The different steps of PROMETHEE can be outlined as 279 indicated by Macharis et al. [59]:

Step 1: Using weights and preference functions, a multi-criteria preference index is defined as 281 in equation (12).

$$
\pi(a, b)=\sum_{j=1}^{k} w_{j} \times P_{j}(a, b)
$$

282

283

284

Where $\pi(a, b)$, expresses the preference degree of "a" over " $b$ " regarding all the criteria, it varies from 0 to 1.

Where wj , is the normalized weight assigned to criterion $\mathrm{j}$

Step 2: The leaving flow Phi+ (Ø+), the entering flow Phi- (Ø-) and the net flow Phi (Ø) are calculated as indicated respectively in equation 13,14 , and 15 . The leaving flow Phi+ $(\varnothing+)$, the entering flow Phi(Ø-) provide the partial ranking PROMETHEE I while the net flow Phi (Ø) provides the complete ranking PROMETHEE II.

$$
\emptyset^{+}(a)=\frac{1}{n-1} \sum_{b \neq a} \pi(a, b)
$$

$$
\emptyset^{-}(\mathrm{a})=\frac{1}{\mathrm{n}-1} \sum_{\mathrm{b} \neq \mathrm{a}} \pi(\mathrm{a}, \mathrm{b})
$$

$$
\emptyset(\mathrm{a})=\emptyset^{+}(\mathrm{a})-\emptyset^{-}(\mathrm{a})
$$

Step 3: The global net flow, which provides the PROMETHEE GDSS ranking of the actions taking into account the group decision preferences is calculated as shown in equation 16:

$$
\emptyset_{g}(a)=\sum_{s=1}^{s} w_{s} \emptyset^{s}(a)
$$


296 As indicated on figure 3, the new fuzzy integrated Delphi- FAHP- FPROMETHEE approach

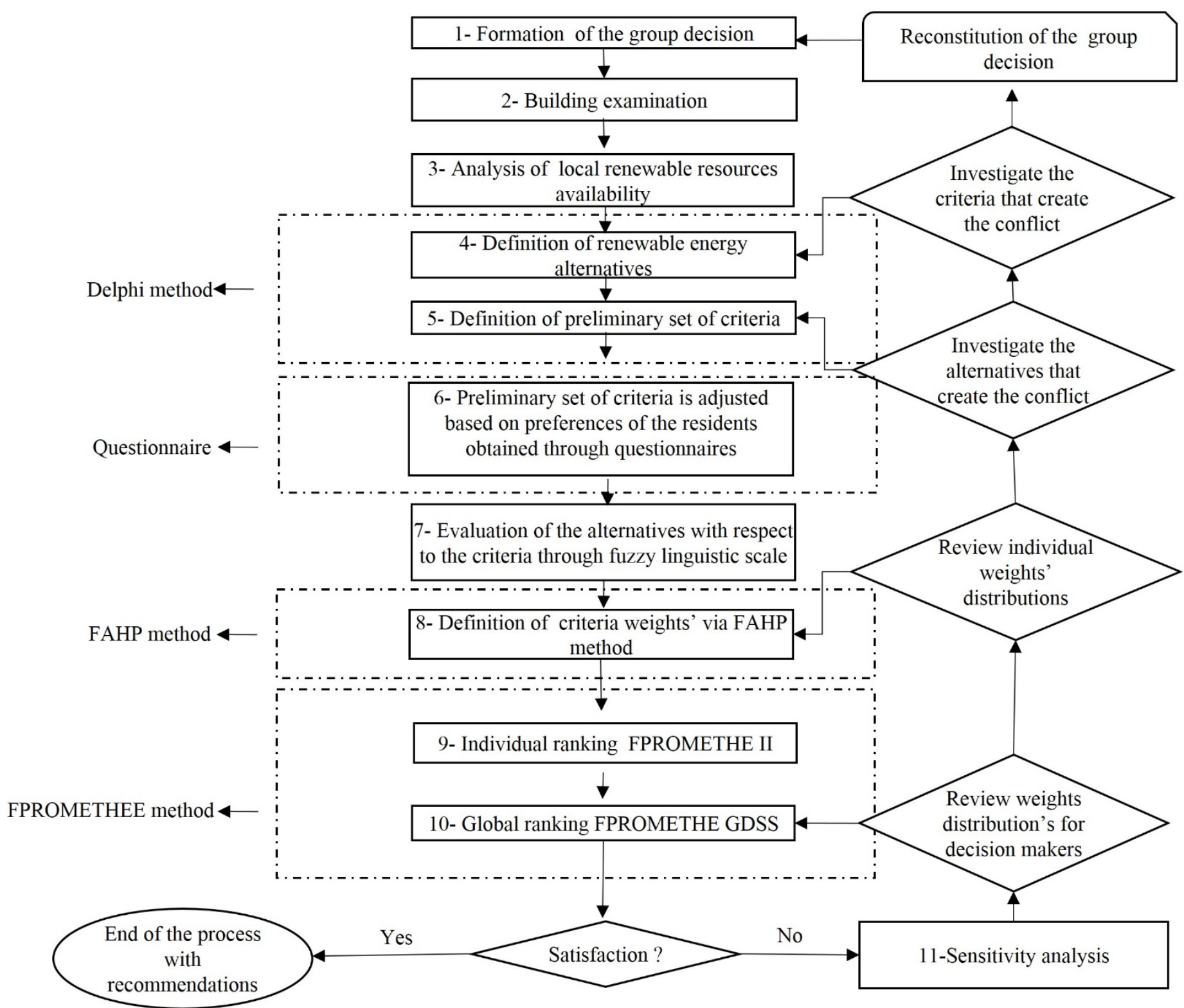


First, a group of decision-makers and experts in renewable energy alternatives is formed (step

1). In step 2, the examination of the building is performed as suggested by Rezaie et al. [69] in putting in evidence the location, the internal organization (plans, sections), the area of the building, the electricity consumption, and the technical equipment's. Later, the local renewable energy resources availability should be investigated as indicated by Rodrigues et al. [70] (step3). The aim of step 3 is only to determine the availability of renewable energy resources in the site location which is the most important criteria. At this specific step, the key question the group decision should consider is how good is the renewable energy (solar, wind, and biomass, etc.) resource on the site location? Further considerations concerning the energy alternatives and evaluation criteria (for e.g. environmental impacts, the amount of physical space required for equipment, site access, inconvenience of the system, grid Interconnection etc.) should be considered in the subsequent steps. For, instance for an economically feasible performance of a wind turbine system, a minimum wind speed should be available on site. Then after, based on the information gathered in step 2 and step 3, the group decision defines through Delphi method a set of renewable energy alternatives for electricity generation (step 4), as well as a set of preliminary evaluation criteria (step5). In step 6, the preliminary set of criteria is adjusted based on the preferences of the residents obtained through questionnaires as indicated by Kontu et al. [17]. Later, each renewable energy alternative is evaluated in terms of all the selected criteria (evaluation table is obtained). In order to deal with the uncertainties concerning the assessments of the alternative, the experts should convert the results of the evaluation table from crisp numbers into a fuzzy linguistic scale as indicated in Gupta et al. [53] ( step 7). In step 8, the FAHP method is used to obtain the weights of the criteria taking into consideration the uncertainties in the experts' judgments. Afterwards, the alternatives are ranked taking into account the uncertainties related to the alternatives' evaluations through individual ranking with 
the PROMETHEE decision making software Visual PROMETHEE [71] is used. At that point, if all the decision makers agree with the results of the global ranking, the process finishes here with recommendations. However, if for some reasons the decision makers disagree with the results it is necessary to solve the conflicts. Macharis et al. [59] have recommended performing a sensitivity analysis in order to deal with conflicts (step 11). First, the weight distributions of the decision makers should be investigated. If the conflict persists, individual weight distributions for each decision maker should be investigated. Special features of the software Visual PROMETHEE as “walking weights” and “stability intervals” help to perform sensitivity analyses. If there is still no agreement, the alternatives that create the conflict should be examined. If the group still cannot reach a consensus, the criteria that create the conflict should be revised. If the conflict continues after all the previous actions, the group decision should be reconstituted. Furthermore, sensitivity analysis is important in order to investigate how changing the weights of the criteria affects the ranking of renewable alternatives.

\section{Application of the proposed methodology}

In this section, a case study is presented. The aim of the case study is to investigate and understand how the proposed methodology in this paper actually works in the real world. The use of a single building as a case study has been commonly considered in the literature of multicriteria decision analysis as a valid approach in order to test new methodologies. A number of studies have used a single building as a case study in order to evaluate the application of multicriteria decision methods for the selection of the best renewable energy alternatives [17, 38, 39, 72, 73]. Likewise, other studies have used a single building as a case study in order to evaluate the application of multi-criteria decision methods for similar purposes, such as the selection of thermal renovation alternatives $[74,75,76,77,78]$, the selection of retrofit measures for heritage buildings [79,40], the selection of sustainable materials for building projects [80], the 
selection of construction method in concrete buildings [81], the selection of façade's alternatives of buildings [82], and the selection of construction equipment [83].

The case study does not aim to generalize the best renewable energy alternatives for electricity generation for a specific type of residential building or a specific region. Moreover, the proposed methodology in this paper considers each project of selection of renewable energy alternatives for electricity generation in a single residential building as a unique project, with its own environment, stockholders, and particularity. The case study was not selected because it is representative of other cases but because the residents, as well as all the stockholders involved in the decision process, were hospitable to the inquiry, which was essential for the application of the proposed method. The research team could easily access the case study and work cooperatively with the participants. Stakeholders involved in the group decision included decision-makers and experts in renewable energy alternatives (step1).

The selected case study was a residential building (see figure 4) located in Oran, Algeria with the latitude 35.711363 and longitude -0.567419 . It is an apartment building constructed by a private developer in 2015 and owned by separate owners. An examination on the building was performed (step2). The building has a rectangular plan of about $400 \mathrm{~m}^{2}$ and is orientated southnorth. Both of the flat roof and the basement include the entire surface of the building and are able to accommodate potential equipment. The ground floor is used for commercial purposes. The building contains 9 floors and 27 apartments in one stairway. The average amount of inhabitants is 90 . The apartments are distributed three per each floor. The living area in the whole building is almost $2295 \mathrm{~m}^{2}$. In all the flats, natural gas is used to heat the spaces and provide hot water, hence electricity is used to provide lightings, usage of appliances, and for the air-conditioning systems to generate cool air during hot summers. The building does not have any mechanic ventilation and is ventilated naturally. The building is supplied from the public electricity grid. 


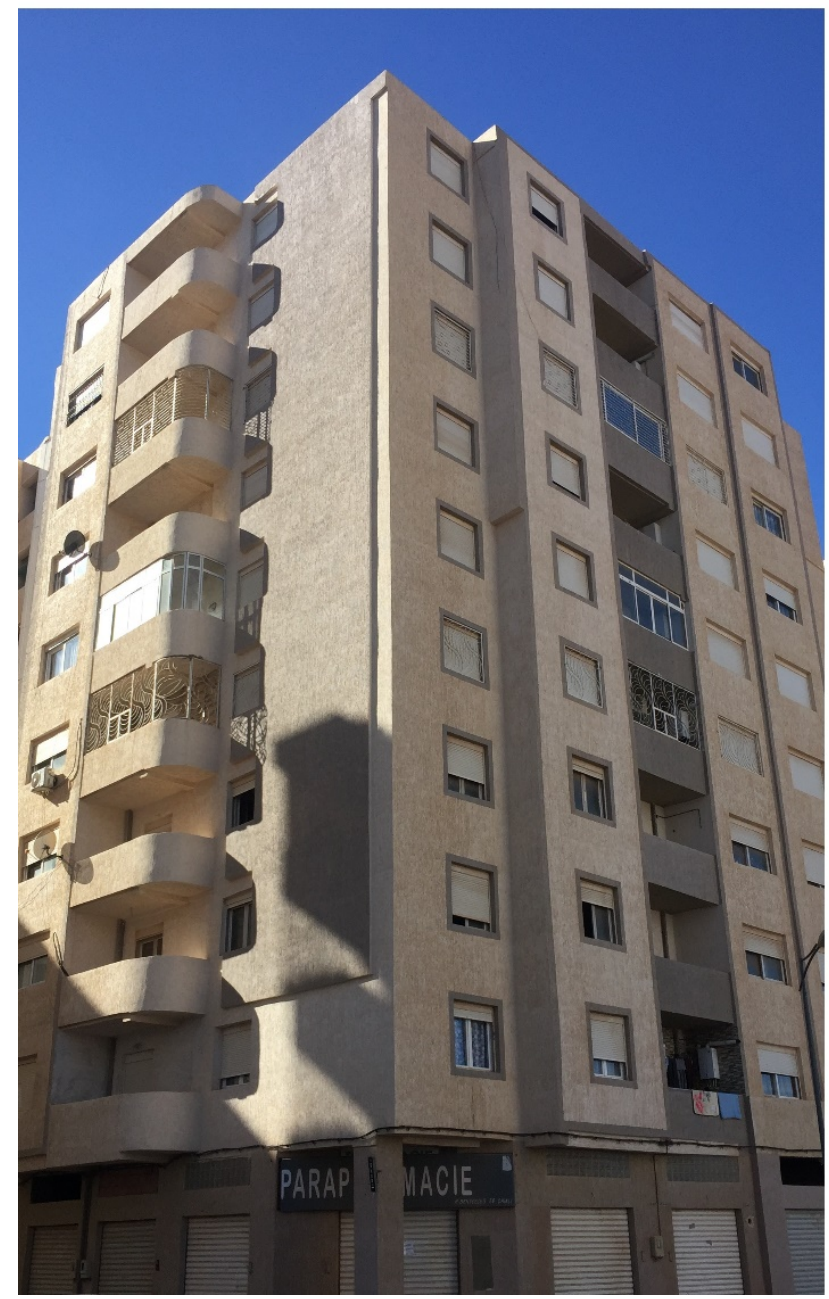

376 Figure 4: The residential building selected as a case study

377 The annual electricity use of the case study investigated in this paper was determined from

378 annual electricity bills provided by the electricity company. The electricity consumption in the

379 whole building is 109, $512 \mathrm{kWh}$ for the entire year, and therefore, the average daily 380 consumption is $300 \mathrm{kWh}$ and Peak load is $75 \mathrm{~kW}$. The electricity consumption for the case 381 study is indicated in figure 5. Note that electricity consumption in June, July, August, and 382 September is higher than the rest of the year due to the need to generate fresh air during hot seasons. 


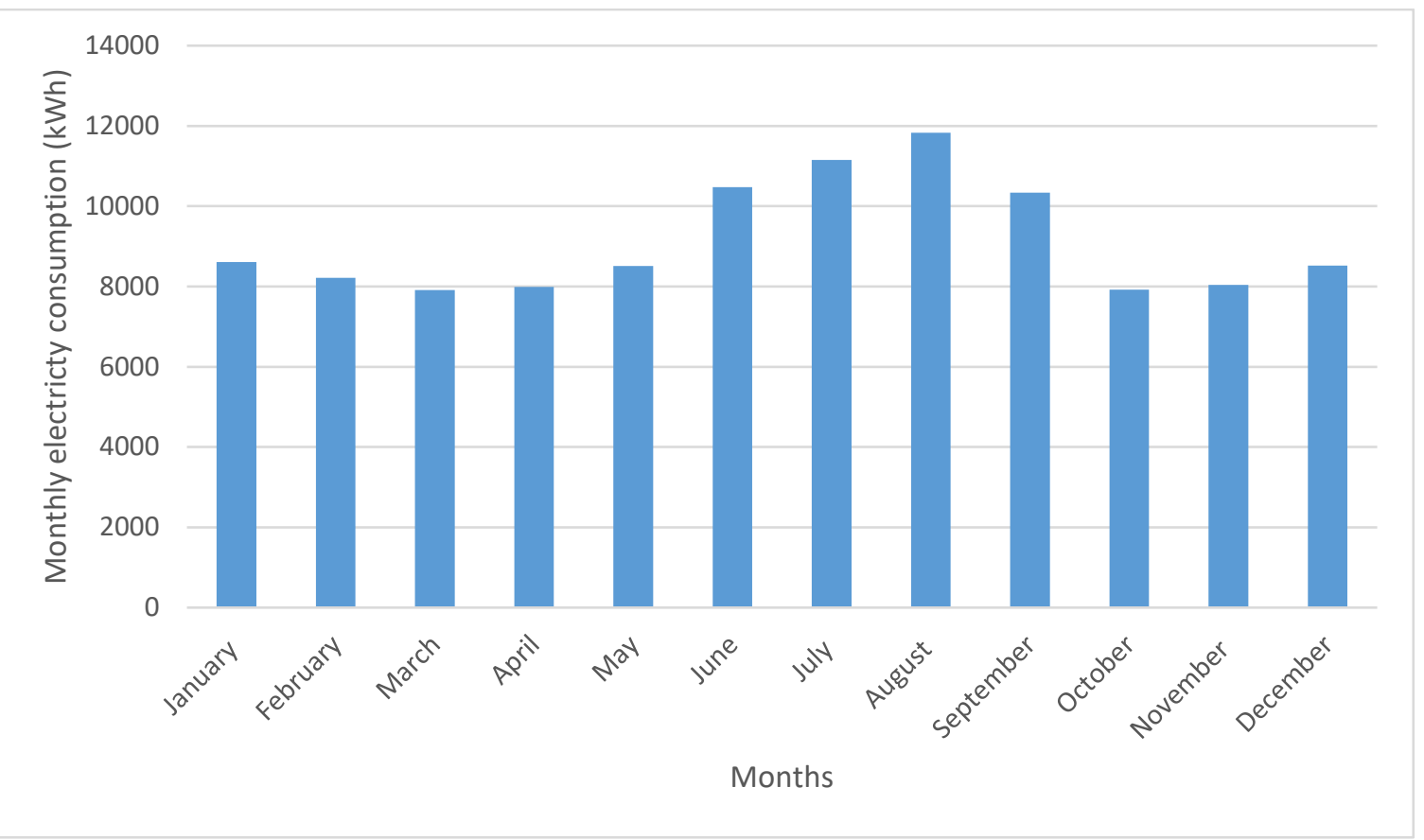

Figure 5: Electricity consumption for the case study

Then, the availability of local renewable energy resources that can be used for electricity generation for the case study were investigated as indicated in step3. Solar, wind, and biomass energy are detailed next. Hydropower and geothermal energy were not investigated, as they are not available on the site location of the residential building investigated (Oran) as indicated in Stambouli [84].

- Solar energy: The availability of solar energy on the ground surface that can be transformed into electricity is essential for an economically feasible performance of solar energy systems [70]. The daily solar radiation profile of the site under study was obtained from NASA Surface Meteorology and Solar Energy database [85]. As indicated on figure 6 , the variation of the solar radiation was found to range from a minimum of 3,151 kWh/m2/day in the month of December to a maximum of 8,245 $\mathrm{kWh} / \mathrm{m} 2 /$ day in the month of June with an annual average solar radiation of 5.2 $\mathrm{kWh} / \mathrm{m} 2 /$ day. According to the quantity of solar radiation on the case study location, it is feasible to consider solar energy as a potential energy source for electricity generation for a residential building [84]. 


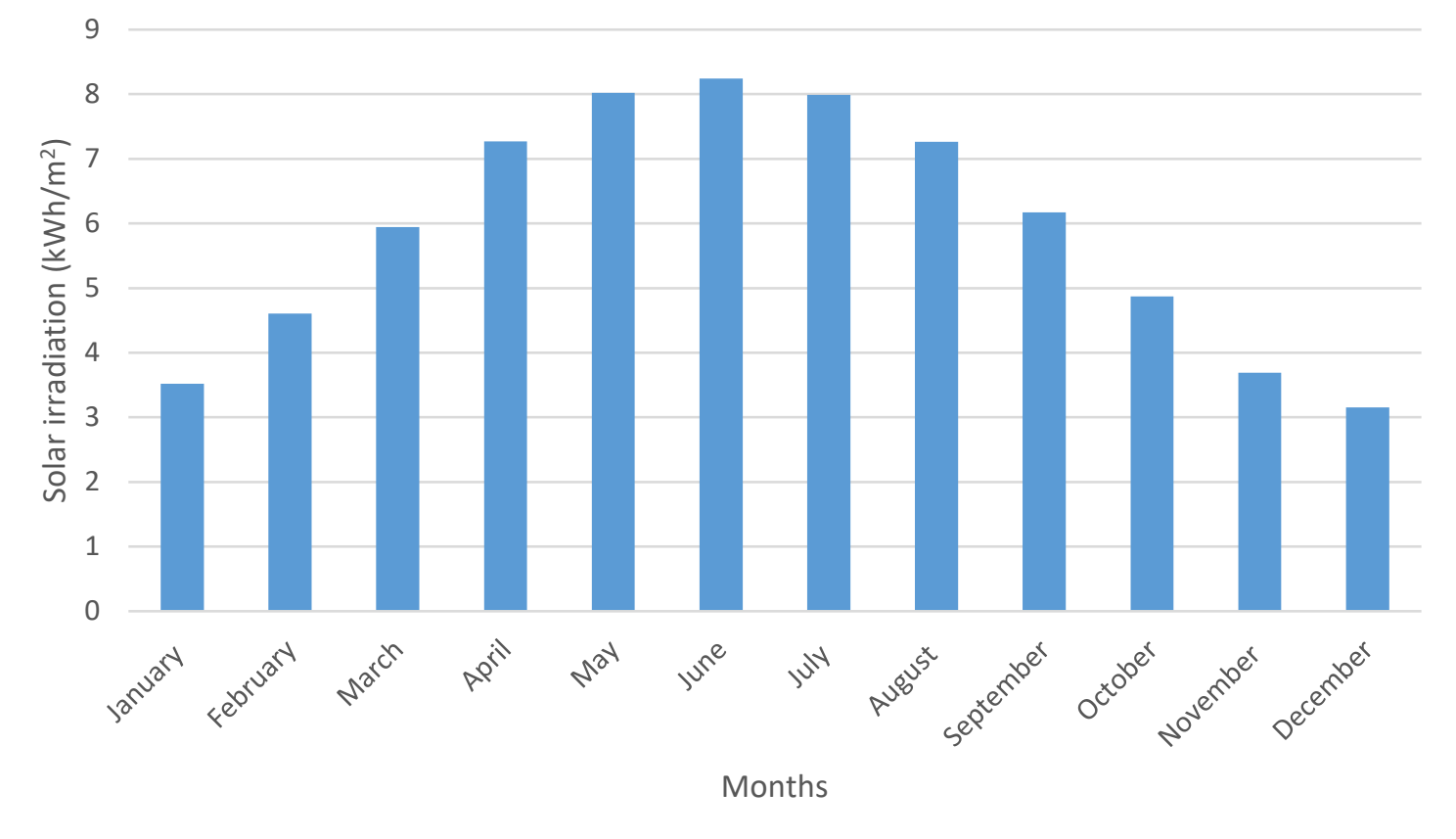

Figure 6: Monthly average of horizontal solar irradiation $\left(\mathrm{kWh} / \mathrm{m}^{2}\right)$

- Wind energy: The potential of wind energy for electricity generation varies according to the availability of the wind resource which depends on the location. Investigating the site- characteristic of wind is an important phase in designing a wind energy alternative [86]. The wind speed variation was taken from NASA Surface Meteorology and Solar Energy database [85]. Figure 7 gives the wind speed profile at the selected site location. At a hub height of $50 \mathrm{~m}$, the wind speed varied from a minimum of $1.2 \mathrm{~m} / \mathrm{s}$ in the month of October to a maximum of $3.7 \mathrm{~m} / \mathrm{s}$ in the month of March with an annual average of $2.008 \mathrm{~m} / \mathrm{s}$. According to Himri et al.[87], wind energy can be feasible where the average wind speed is higher than 5-6 m/s. Since the annual average wind speed is about 2.008 $\mathrm{m} / \mathrm{s}$, it is not feasible to consider wind energy as a potential energy source for electricity generation for a residential building. 


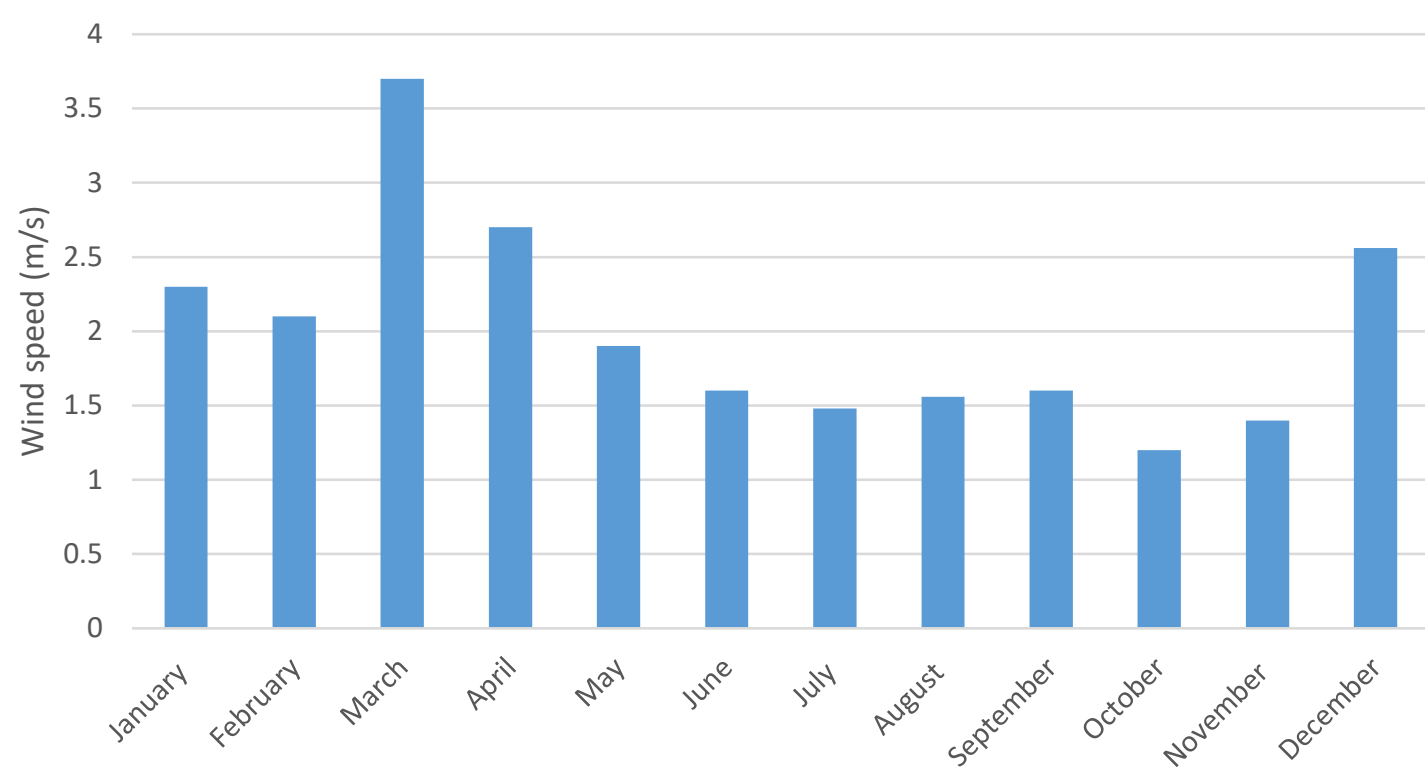

Months

Figure 7: Monthly average wind speed (m/s)

- Biomass: According to Alfonso et al. [88], the availability of biomass raw materials should be considered as the main criterion for energy production. In the case study location (Oran, Algeria), the biomass eventually offers great possibilities for electricity generation in residential buildings with the main source of biomass coming from forest, agricultural and urban wastes [84]. However, biomass materials used to get the energy are not mature and are not being promoted for commercialisation. Hence the market of the wood in all of its forms in Oran and more generally in Algeria is underdeveloped and thus makes the use of wood resource for energy production an unattractive investment opportunity. Additionally, the agriculture and energy sectors are completely unrelated which makes the use of agricultural wastes for energy production very complicated [84]. According to Stambouli et al. [86], municipal solid waste (MSW) seems to be an efficient way to produce electricity for residential buildings as the quantity of MSW per Algerian is about $1 \mathrm{~kg} /$ day, and this number is expected to grow rapidly. The electricity generation from biomass can be possible through thermochemical (combustion, gasification, and pyrolysis) and biological conversion 
processes $[89,90]$. Consequently, since the case study presented in this paper is located in an urban area (Oran), the MSW as a source of biomass for electricity generation is considered as a potential alternative. Initial research has been conducted in the field of utilising biomass energy resource from municipal waste in Algeria [91]. Later, according to the investigation results of the availability of local renewable energy resources that can be used for electricity generation for the case study, the group decision has defined through Delphi method set of renewable energy alternatives for electricity generation (step 4). The alternatives considered in this paper are:

- Fixed roof mount photovoltaic (PV) system: The PV panel does not follow the sun's movement and is fixed at the tilt and azimuth angles. The system consists of different components: field of collectors with 222 photovoltaic solar panels with a total capacity of $74.416 \mathrm{~kW}$ dc, the total module area is about $362 \mathrm{~m}^{2}$. In order to convert the PV modules DC output to AC compatible with the building’s loads, 20 inverters with a total capacity of $76.000 \mathrm{~kW}$ ac are used (the DC to AC ratio is 0.98 ). The system is connected to the grid, to enable the power exchange between the grid and the system in case of surplus or deficiency.

- 1 Axis tracking photovoltaic system: The PV panel has one axis fixed by the value of tilt and the other axis rotates about the tilted axis from east to west tracking the daily sun's movement. The composition of the system is similar to the fixed roof mount photovoltaic (PV) system.

- 2 Axis tracking photovoltaic system: The PV panel rotates from east to west tracking the daily sun's movement and from north to south to track the sun's seasonal movement throughout the year. The composition of the system is similar to the fixed roof mount photovoltaic (PV) system and the 1 Axis tracking photovoltaic system. 

system uses a $75 \mathrm{~kW}$ direct combustion generator (DCG) and consumes almost $500 \mathrm{~kg}$ of biomass (M.S.W) per day. In this process, a storage tank is used to store biomass wastes, and a direct combustion boiler is used for combustion. The steam obtained from the combustion is used to produce electricity using a steam turbine and a generator [92]. The system is connected to the grid, to enable the power exchange between the grid and the system in case of surplus or deficiency.

- Hybrid biomass and photovoltaic system: The hybrid energy system consists of $30 \mathrm{~kW}$ direct combustion generator power system which consumes almost $200 \mathrm{~kg}$ of biomass (M.S.W) per day and 132 photovoltaic solar panels with a total capacity of $44.247 \mathrm{~kW}$ dc. In order to convert the PV modules DC output to AC compatible with the buildings loads, 12 inverters with a total capacity of $45.600 \mathrm{~kW}$ ac are used (the DC to AC ratio is 0.97 ). The proposed hybrid system is designed to provide approximately $40 \%$ of energy from the biomass, and $60 \%$ from PV. The system is connected to the grid, to enable the power exchange between the grid and the system in case of surplus or deficiency. Figure 8 shows the schematic diagram of hybrid biomass and photovoltaic system connections

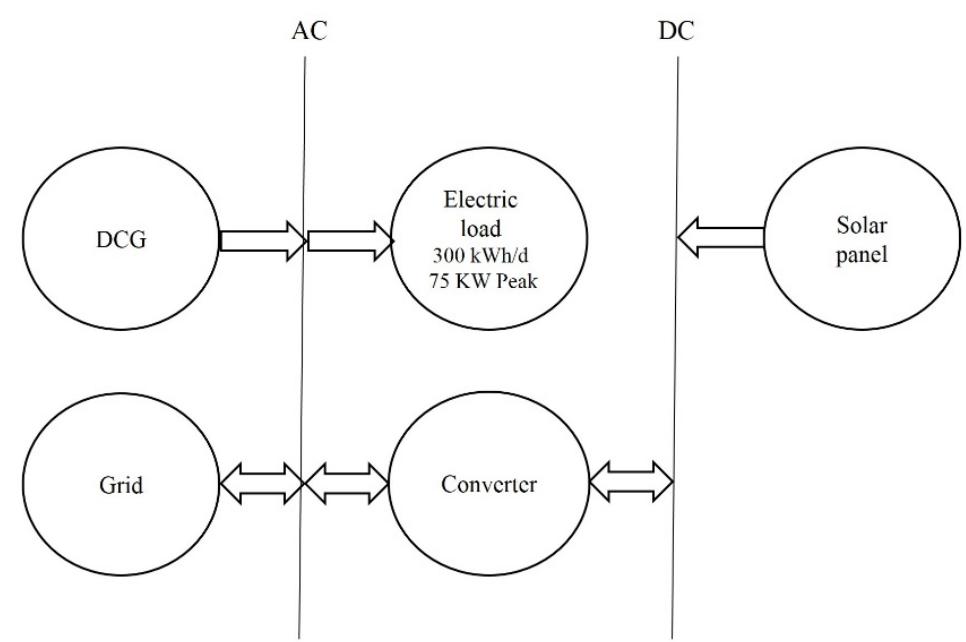

Figure 8: Hybrid biomass and photovoltaic system connection 
Then, as indicated in table 3, a set of preliminary evaluation criteria was defined (step5).

Table 3: Preliminary set of evaluation criteria defined by the group decision

\begin{tabular}{|c|c|c|}
\hline & Criteria & Description \\
\hline \multirow[t]{5}{*}{ Economic } & Investment cost & $\begin{array}{llll}\text { Investment cost include equipment and } \\
\text { installation costs }\end{array}$ \\
\hline & Internal rate of return & $\begin{array}{l}\text { Used to evaluate the desirability of } \\
\text { investments or projects }\end{array}$ \\
\hline & Operational costs & $\begin{array}{l}\text { Operational costs include monitoring, } \\
\text { maintenance, and repair. }\end{array}$ \\
\hline & Net present Value (NPV) & $\begin{array}{l}\text { Is a measure of a project's economic feasibility } \\
\text { that includes both savings and cost }\end{array}$ \\
\hline & Payback period & $\begin{array}{l}\text { Payback period represents the threshold where } \\
\text { savings have exceeded costs }\end{array}$ \\
\hline Energetic & $\begin{array}{ll}\text { Energy } & \text { production } \\
(\mathrm{kWh} / \text { year) }\end{array}$ & $\begin{array}{l}\text { Total quantity of electricity generated by the } \\
\text { system in Year }\end{array}$ \\
\hline \multirow[t]{2}{*}{ Environmental } & $\mathrm{CO}_{2}$ reduction $(\mathrm{kg} /$ year $)$ & $\begin{array}{l}\text { The potential of renewable } \\
\text { resources alternatives to reduce } \mathrm{CO}_{2} \text { emissions }\end{array}$ \\
\hline & $\begin{array}{l}\text { Life-cycle environmental } \\
\text { impacts }\end{array}$ & $\begin{array}{l}\text { Environmental impacts related with all the } \\
\text { phases of a renewable energy alternatives life's }\end{array}$ \\
\hline \multirow[t]{3}{*}{ Technology } & Availability & $\begin{array}{l}\text { The availability of energy sources that supply } \\
\text { the system }\end{array}$ \\
\hline & Efficiency & $\begin{array}{l}\text { Discusses the quantity of energy that can be } \\
\text { obtained from an energy source }\end{array}$ \\
\hline & Reliability & $\begin{array}{l}\text { The ability of a system to produce energy as } \\
\text { planned }\end{array}$ \\
\hline \multirow[t]{2}{*}{ Social } & Social acceptability & $\begin{array}{l}\text { The preferences of the residents concerning the } \\
\text { renewable energy alternatives }\end{array}$ \\
\hline & $\begin{array}{l}\text { Inconvenience of the } \\
\text { system }\end{array}$ & $\begin{array}{l}\text { Inconvenience caused to the residents by the } \\
\text { renewable energy alternatives }\end{array}$ \\
\hline \multirow[t]{2}{*}{ Usability } & Ease of use & $\begin{array}{l}\text { Indicate how easy the renewable energy } \\
\text { alternatives are to use for the residents }\end{array}$ \\
\hline & Disponibility & $\begin{array}{l}\text { Refers to the disponibility of renewable energy } \\
\text { technologies on the market }\end{array}$ \\
\hline
\end{tabular}

478 Then after, a questionnaire was conducted with the residents of the case study presented in this

479 research. The main objective of the questionnaire was to determinate the criteria preferences of

480 the inhabitants of the single residential building investigated in this paper. The survey was

481 divided into two parts, as indicated in table 4. The first part aims to obtain basic information of

482 the respondents. The second part details 15 different possible criteria for the evaluation of the

483 selected renewable energy alternatives. The respondents were asked to evaluate each single 
criteria using a five-point scale, where 1 meant that the criterion was not important while 5 meant that the criterion was very important. As the respondents were the residents of the building investigated in this paper, their number was limited to the total amount of the apartments in the building, which was 27 (with one respondent per apartment). Altogether 27 inhabitants of the residential building, representing different demographic groups, answered the questionnaire. The 27 residents did not have any knowledge and understanding of renewable energy. The number of respondents in this case study was sufficient for the analysis of the fivepoint scale data. The statistical analysis was performed by calculating the average score of each criteria as indicated in Kontu et al. [17]. The results show that the respondents valuate economic criteria such as investment cost (average score 4.5, answering scale from 1 to 5 as seen in table 4) and payback period (4.2) as well as energetic criteria such as energy production (4.2). Respondents considered the $\mathrm{CO}_{2}$ reduction (4.1) more important than life-cycle environmental impacts (3.0). Respondents also valuate usability criteria such as ease of use (4.3) and disponibility (4.2). Technology criteria such as availability (2.1), efficiency (2.2), reliability (2.3) and social criteria such as social acceptability (2.0) and inconvenience of the system (2.4) were considered as the least important criteria for the respondents. The number of the respondents was limited and do not represent an impartial sample of the population. Nevertheless, the respondents represent the residents of the building investigated in this paper. Consequently, it is necessary to take into account their preferences in order to select the best renewable energy alternative for electricity generation. One should notice that the results of the survey are specific to this case study and different results could be obtained if the same survey is repeated in another building or area. Hence, the average scores of criteria might be completely different from one building to another according to residents' preferences. For instance, residents of one specific building could valuate economic criteria while residents of another building could valuate technology criteria. 
Table 4: The questionnaire conducted with the residents

\begin{tabular}{|c|c|c|}
\hline Question topic & Question & Answer \\
\hline $\begin{array}{l}\text { Information of the } \\
\text { answerer }\end{array}$ & $\begin{array}{l}\text { Gender } \\
\text { Age } \\
\text { Profession }\end{array}$ & $\begin{array}{l}\text { F/M } \\
\text { Open } \\
\text { Open }\end{array}$ \\
\hline Criteria & $\begin{array}{l}\text { Investment cost, Internal rate of return, } \\
\text { Operational costs, Net present Value } \\
\text { (NPV) Payback period, Energy } \\
\text { production (kWh/year), } \mathrm{CO}_{2} \text { reduction } \\
\text { (kg/year), Life-cycle environmental } \\
\text { impacts, Availability, Efficiency, } \\
\text { Reliability, Social acceptability, } \\
\text { Inconvenience of the system, Ease of } \\
\text { use , Easy to acquire }\end{array}$ & $\begin{array}{l}(1=\text { not important, } 5=\text { very } \\
\text { important })\end{array}$ \\
\hline
\end{tabular}

Table 5 shows the evaluations in crisp numbers of all the alternatives in term of the selected criteria. The calculations procedures of the evaluations are presented below:

The energy production, $\mathrm{CO}_{2}$ reduction (kg/year), and the economic analysis of the different systems have been achieved with the software HOMER [93]. HOMER is a computer model that facilitates the evaluation of design options for both off-grid and-grid connected power systems taking into account the variation in technology costs and energy resource availability [94].

- Investment cost: The investment cost of a component is the total installed cost of that component at the beginning of the project which includes the following costs: renewable energy system, mounting hardware, tracking system types for PV panels, wiring, and installation. For instance, the investment cost of a fixed roof mount PV system is specified under Homer software at \$2,930/kW.

- Payback period: The payback period was calculated using HOMER software by comparing one system to another. The payback is the number of years it takes for the cumulative income to equal the value of the initial investment. 
- Energy production: The energy performance represents the total amount of electrical energy produced annually by the renewable components of the power system. For instance, Homer pro uses the following equation to calculate the output of the PV array:

$$
P_{P V}=Y_{P V} f_{P V}\left(\frac{\overline{G_{T}}}{\overline{G_{T, S T C}}}\right)\left[1+\alpha_{P}\left(T_{C}-T_{C, S T C}\right)\right]
$$

Where:

$Y_{P V}=$ the rated capacity of the PV array, meaning its power output under standard test conditions $[\mathrm{kW}]$

$f_{P V}=$ the PV derating factor $[\%]$

$\overline{G_{T}}=$ the solar radiation incident on the PV array in the current time step [kW/m2]

$\overline{G_{T, S T C}}=$ the incident radiation at standard test conditions $[1 \mathrm{~kW} / \mathrm{m} 2] \alpha_{P}=$ the temperature coefficient of power $\left[\% /{ }^{\circ} \mathrm{C}\right]$

$T_{c}=$ the PV cell temperature in the current time step $\left[{ }^{\circ} \mathrm{C}\right]$

$T_{c, S T C}=$ the PV cell temperature under standard test conditions $\left[25^{\circ} \mathrm{C}\right]$

- CO2 reduction: $\mathrm{CO} 2$ reduction was calculated by using the following equation:

$\mathrm{CO}_{2}$ reduction $=\mathrm{CO}_{2}$ emissions of the non-renewable power system as the base case $-\mathrm{CO}_{2}$ emissions of the renewable power system Where: $\mathrm{CO}_{2}$ emissions of the non-renewable power system as the base case were calculated by converting the annual electricity consumption ( $\mathrm{kWh} /$ year) to $\mathrm{CO}_{2}$ emissions (kg/year). The conversion factor is $0.547 \mathrm{~kg} \mathrm{CO} 2$ released for each $\mathrm{kWh}$ produced from natural gas resources. The factor is based on the carbon emissions generated by the current Algerian power stations per kWh generated [95]. $\mathrm{CO}_{2}$ emissions of each different renewable power system were evaluated using Homer software. 
- Usability: The usability was directly expressed on a qualitative scale. It was evaluated by means of expert judgments during open discussions taking into account how easy the renewable energy alternatives are to use for the residents as well as the disponibility of renewable energy technologies on the market.

Subsequently, as it is indicated in table 6, the experts have converted the results of table 5 from crisp numbers into a fuzzy linguistic scale (step7).

Table 5: Evaluations in crisp numbers of all the alternatives in term of the selected criteria

\begin{tabular}{|c|c|c|c|c|c|c|c|c|}
\hline $\begin{array}{l}\text { Renewable } \\
\text { resource }\end{array}$ & $\begin{array}{l}\text { Availability of } \\
\text { renewable resources } \\
\text { on the location of the } \\
\text { case study }\end{array}$ & \begin{tabular}{|l|} 
Energy \\
Technology \\
\end{tabular} & Item & $\begin{array}{l}\text { Investment } \\
\text { cost } \\
\text { Us dollar }\end{array}$ & $\begin{array}{l}\text { Payback } \\
\text { period } \\
\text { Years }\end{array}$ & $\begin{array}{l}\text { Energy } \\
\text { production } \\
\text { (kWh/year) }\end{array}$ & $\begin{array}{l}\mathrm{CO}_{2} \\
\text { reduction } \\
\text { (kg/year) }\end{array}$ & Usability \\
\hline \multirow[t]{3}{*}{ Solar } & \multirow[t]{3}{*}{ Available } & $\begin{array}{c}\text { Fixed roof mount } \\
\text { photovoltaic } \\
\text { system }\end{array}$ & $\begin{array}{c}222 \text { solar } \\
\text { panels } \times 335 \mathrm{~W}\end{array}$ & 218,168 & 13 & 110,261 & $51,066.50$ & $\begin{array}{l}\text { Very } \\
\text { good }\end{array}$ \\
\hline & & \begin{tabular}{|c|}
$\begin{array}{c}1 \text { Axis tracking } \\
\text { photovoltaic } \\
\text { system }\end{array}$ \\
\end{tabular} & $\begin{array}{c}222 \text { solar } \\
\text { panels } \times 335 \mathrm{~W}\end{array}$ & $263,983.28$ & 11 & 133,604 & $63,020.75$ & $\begin{array}{l}\text { Very } \\
\text { good }\end{array}$ \\
\hline & & $\begin{array}{c}2 \text { Axis tracking } \\
\text { photovoltaic } \\
\text { system }\end{array}$ & $\begin{array}{c}222 \text { solar } \\
\text { panels } \times 335 \mathrm{~W}\end{array}$ & $270,528.32$ & 10.5 & 142,252 & $67,100.00$ & $\begin{array}{l}\text { Very } \\
\text { good }\end{array}$ \\
\hline Wind & $\begin{array}{l}\text { Not available on the } \\
\text { case study location }\end{array}$ & - & - & - & - & - & - & \\
\hline Biomass & Available & $\begin{array}{c}\text { Biomass through } \\
\text { direct combustion } \\
\text { process of } \\
\text { Municipal Solid } \\
\text { Waste (M.S.W) }\end{array}$ & \begin{tabular}{|c}
$75 \mathrm{~kW}$ \\
direct \\
combustion \\
generator \\
power system
\end{tabular} & $187,669.00$ & 11 & 109,444 & $51,382.15$ & Very bad \\
\hline $\begin{array}{l}\text { Biomass and } \\
\text { Solar }\end{array}$ & Available & $\begin{array}{c}\text { Hybrid biomass } \\
\text { through direct } \\
\text { combustion of } \\
\text { M.S.W and } \\
\text { photovoltaic } \\
\text { system }\end{array}$ & $\begin{array}{c}30 \mathrm{~kW} \text { direct } \\
\text { combustion } \\
\text { generator } \\
\text { power system } \\
+ \\
132 \text { solar } \\
\text { panels } \times 335 \mathrm{~W}\end{array}$ & 204,867 & 12 & 109,993 & $51,855.47$ & Medium \\
\hline Geothermal & $\begin{array}{l}\text { Not available on the } \\
\text { case study location }\end{array}$ & - & - & - & & - & F & \\
\hline Hydro & $\begin{array}{l}\text { Not available on the } \\
\text { case study location }\end{array}$ & - & - & - & & - & - & \\
\hline
\end{tabular}

554 Table 6: Evaluations in fuzzy linguistic scale of all the alternatives in term of the selected

\begin{tabular}{|l|l|l|l|l|l|l|}
\hline Energy Technology & Item & Investment cost & $\begin{array}{l}\text { Payback } \\
\text { period }\end{array}$ & $\begin{array}{l}\text { Energy } \\
\text { production }\end{array}$ & $\mathrm{CO}_{2}$ reduction & Usability \\
\hline
\end{tabular}




\begin{tabular}{|c|c|c|c|c|c|c|}
\hline $\begin{array}{c}\text { Fixed roof mount } \\
\text { photovoltaic system }\end{array}$ & $\begin{array}{c}222 \text { solar panels } \times \\
\text { 335W }\end{array}$ & Good & Bad & Good & Good & Very good \\
\hline $\begin{array}{c}1 \text { Axis tracking } \\
\text { photovoltaic system }\end{array}$ & $\begin{array}{c}222 \text { solar panels } \times \\
335 \mathrm{~W}\end{array}$ & Medium & Good & Very good & Very good & Very good \\
\hline $\begin{array}{c}2 \text { Axis tracking } \\
\text { photovoltaic system }\end{array}$ & $\begin{array}{c}22 \text { solar panels } \times \\
\text { 335W } \\
\end{array}$ & Medium & Very good & Very good & Very good & Very good \\
\hline $\begin{array}{l}\text { Biomass through direct } \\
\text { combustion process of } \\
\text { Municipal Solid Waste } \\
\text { (M.S.W) }\end{array}$ & $\begin{array}{c}75 \mathrm{~kW} \\
\text { direct combustion } \\
\text { generator power } \\
\text { system }\end{array}$ & Medium & Good & Good & Good & Very bad \\
\hline $\begin{array}{l}\text { Hybrid biomass through } \\
\text { direct combustion of } \\
\text { M.S.W and photovoltaic } \\
\text { system }\end{array}$ & $\begin{array}{c}30 \mathrm{~kW} \text { direct } \\
\text { combustion } \\
\text { generator power } \\
\text { system } \\
+ \\
132 \text { solar panels } \times \\
\text { 335W }\end{array}$ & Good & Medium & Good & Good & Medium \\
\hline
\end{tabular}

After, the FAHP method was implemented in order to assign weights to the evaluation criteria

558 (Investment cost, Payback period, Energy production, $\mathrm{CO}_{2}$ reduction, Usability) taking into account uncertainties in expert's and decision makers judgments (step8). First, each member of the group decision has performed a pairwise comparison of the evaluation criteria using a fuzzy linguistic scale as indicated in figure 2. Then, the linguistic judgments of each member of the project team were converted to triangular fuzzy numbers as indicated in table 2. Later, the weighted comparison matrix for all the members of the group decision was calculated using equations (3) and (4). Then after, using respectively equation (5) and equation (6) the sum of the individual rows and the total sum of all the rows are calculated. Subsequently, the sum of each row is divided by the total sum of all the rows using equation (7). Table 7 shows the weighted comparison matrix for all the group decision members as well as the results of equations (5), (6), and (7).

569 Then, the degree of possibility of $\tilde{S}_{i} \geq \tilde{S}_{j}$ j where $i, j=1, \ldots, n ; j \neq i$ is calculated using

570 equations (8) and (9). For instance, the calculations for the degree of possibility of $\tilde{S}_{1} \geq \tilde{S}_{2}$,

$571 \quad \tilde{S}_{1} \geq \tilde{S}_{3}, \tilde{S}_{1} \geq \tilde{S}_{4}, \tilde{S}_{1} \geq \tilde{S}_{5}$ are presented below: 
$572 \quad$ As $m_{i} \geq m_{j}, V\left(\tilde{S}_{1} \geq \tilde{S}_{2}\right)=1$

$573 \quad$ As $m_{i} \geq m_{j}, V\left(\tilde{S}_{1} \geq \tilde{S}_{3}\right)=1$

$574 \quad$ As $m_{i} \geq m_{j}, V\left(\tilde{S}_{1} \geq \tilde{S}_{4}\right)=1$

$575 \quad$ As $m_{i} \geq m_{j}, V\left(\tilde{S}_{1} \geq \tilde{S}_{5}\right)=1$

576 Consequently, the weight vector W' computed as in equation, (10) and (11) is:

$577 \mathrm{~d}^{\prime}(\mathrm{C} 1)=\mathrm{V}(\mathrm{S} 1 \geq \mathrm{S} 2, \mathrm{~S} 3, \mathrm{~S} 4, \mathrm{~S} 5)=\min (1.00,1.00,1.00,1.00)=1$

578 Similarly, the computed values for d' (C2), d' (C3), d' (C4), and d' (C5) were respectively 0.88,

579 0.94, 0.77 and 0.83. Finally, the calculated values d' (C1), d' (C2), d' (C3), d' (C4), and d' (C5)

580 were normalized in order to define the weights (wj) of the objectives. According to the project

581 team judgments, the weights were as follow: the investment cost $(0.222)$, the payback period

582 (0.197), the energy production (0.209), the $\mathrm{CO}_{2}$ reduction $(0.172)$, and the usability $(0.185)$.

583 Table 7: Weighted comparison matrix for the group decision

\begin{tabular}{|c|c|c|c|c|c|c|c|}
\hline & C1 & $\mathrm{C} 2$ & C3 & $\mathrm{C} 4$ & $\mathrm{C} 5$ & $\begin{array}{l}\text { Sum of row } \\
\text { elements }\end{array}$ & $\begin{array}{l}\text { Dividing each row } \\
\text { sum by sum total } \\
\text { of all rows }\end{array}$ \\
\hline C1 & $(1,1,1)$ & $\begin{array}{l}(1.25,1.75,2 . \\
25)\end{array}$ & $(1,1.375,1.75)$ & $\begin{array}{l}(2.125,2.625 \\
, 3.125)\end{array}$ & $\begin{array}{l}(1.25,1.75, \\
2.25)\end{array}$ & $\begin{array}{l}\text { (6.625,7.5, } \\
9.375)\end{array}$ & $\begin{array}{l}(0.266,0.259, \\
0.245)\end{array}$ \\
\hline $\mathrm{C} 2$ & $\begin{array}{l}(0.641,0.76 \\
6,1.25)\end{array}$ & $(1,1,1)$ & $(0.79,1,1.25)$ & $\begin{array}{l}\text { (1,1.375,1.7 } \\
5)\end{array}$ & $\begin{array}{l}(1,1.375,1 . \\
75)\end{array}$ & $\begin{array}{l}\text { (4.431,5.31, } \\
7)\end{array}$ & $\begin{array}{l}0.178,0.183, \\
0.183)\end{array}$ \\
\hline $\mathrm{C} 3$ & $\begin{array}{l}\text { ( } \\
0.79,1,1.25\end{array}$ & $\begin{array}{l}(1,1.375,1.75 \\
)\end{array}$ & $(1,1,1)$ & $\begin{array}{l}(1.75,2.25,2 . \\
75)\end{array}$ & $\begin{array}{l}(1.25,1.75, \\
2.25)\end{array}$ & $\begin{array}{l}(5.79, \\
6.625,9)\end{array}$ & $\begin{array}{l}\text { (0.232,0.229, } \\
0.235)\end{array}$ \\
\hline $\mathrm{C} 4$ & $\begin{array}{l}(0.466,0.68 \\
3,1.125)\end{array}$ & $(0.79,1,1.25)$ & $(0.79,1,1.25)$ & $(1,1,1)$ & $\begin{array}{l}(0.641,0.7 \\
66,1.25)\end{array}$ & $\begin{array}{l}(3.687,4.446, \\
5.875)\end{array}$ & $\begin{array}{l}\text { (0.148,0.153, } \\
0.153)\end{array}$ \\
\hline $\mathrm{C} 5$ & $\begin{array}{l}(0.640, \\
0.833,1.25)\end{array}$ & $\begin{array}{l}(1.25,1.75,2 . \\
25)\end{array}$ & $\begin{array}{l}\text { (0.641,0.766, } \\
1.25)\end{array}$ & $\begin{array}{l}(0.79,1,1.25 \\
)\end{array}$ & $(1,1,1)$ & $\begin{array}{l}\text { (4.321,5.349, } \\
7)\end{array}$ & $\begin{array}{l}\text { (0.173,0.184, } \\
0.183)\end{array}$ \\
\hline
\end{tabular}


C1: Investment cost; C2: Payback period; C3: Energy production, C4: $\mathrm{CO}_{2}$ reduction $\mathrm{C} 5$ :

585

586

587

588

589

590

591

Usability

Then, a global ranking FPROMETHE GDSS according to the expert's preferences was performed under Visual PROMETHEE software [71] as indicated in step 9 and 10. The results point out that 2 Axis tracking PV is the best alternative with a phi net flow of 0.471 followed respectively by, 1 Axis tracking PV with a phi net flow of 0.321 , fixed roof mount PV with a phi net flow of -0.130 , hybrid biomass and PV system with a phi net flow of -0.218 , and biomass with a phi net flow of -0.443 (see figure 9).

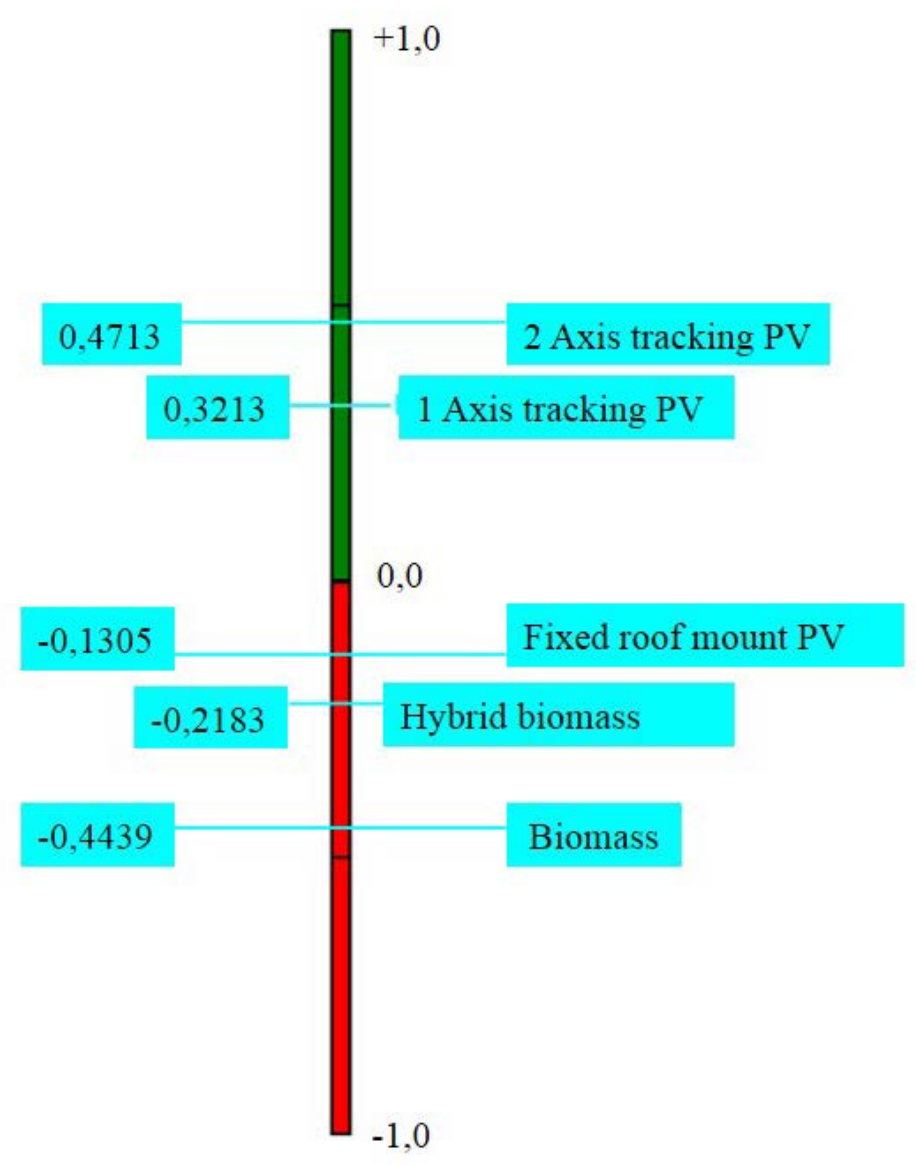

592 
Good and weak features of each alternative are explained in figure 10 in putting in evidence the details of Phi net flow for the group decision. Each renewable alternative is represented by a bar. The features of different criteria on each bar were indicated using a colour coding of the criteria. The different impacts of criteria on the Phi net flow of an action correspond to the different parts of a bar. Negative (downward) parts correspond to weak features while positive (upward) parts correspond to good features. The Phi score is equal to the balance between positive and negative parts in each bar. The renewable energy alternatives were ranked from left to right according to the FPROMETHEE GDSS global ranking.

As shown in figure 10, the 2 Axis tracking PV system had very good characteristics in both the payback period and the energy production. It had good characteristics in the $\mathrm{CO}_{2}$ reduction as well as the usability. However, it had weak characteristics in the investment cost. The 1 Axis tracking PV system had very good characteristics in the energy production and the $\mathrm{CO}_{2}$ reduction. It had good characteristics in the usability and the payback period and weak characteristics in the investment cost. The Fixed roof mount PV system had very good characteristics in the investment cost. It had good characteristics in the usability and weak characteristics in the energy production and the $\mathrm{CO}_{2}$ reduction while it had very weak characteristics in the payback period. The Hybrid biomass and PV system had very good characteristics in the investment cost. It had weak characteristics in the usability, the energy production, the $\mathrm{CO}_{2}$ reduction and the payback period. The biomass system had good characteristics in the investment cost. It had weak characteristics in the energy production, the $\mathrm{CO}_{2}$ reduction and the payback period while it had very weak characteristics in the usability. 


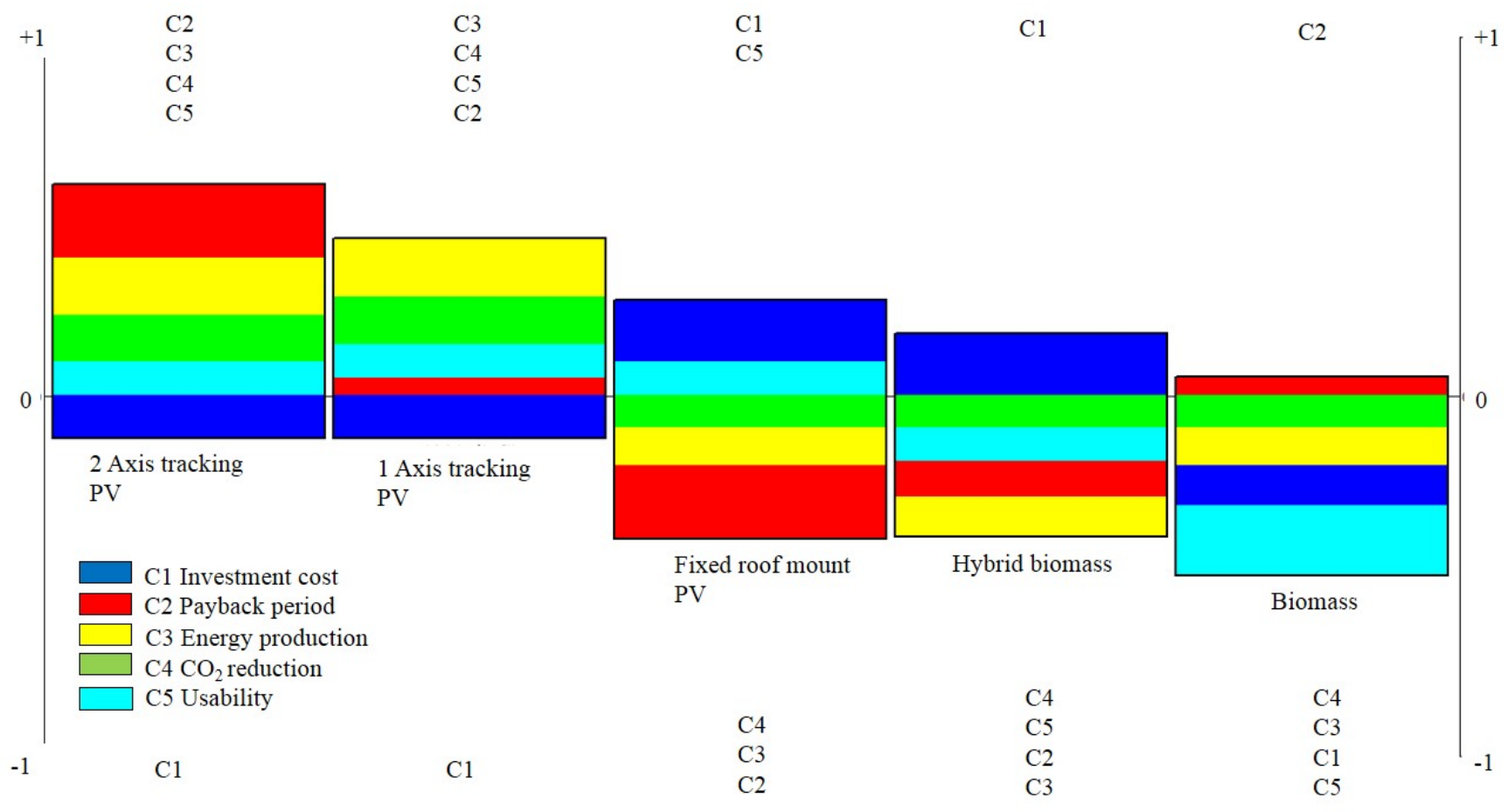

Figure 10: Details of the phi net flow computation for the group decision

618 The group decision agreed that 2 Axis tracking PV is the best renewable alternative for electricity generation for the case study, consequently the sensitivity analysis to solve conflicts was not required. However, since the fuzzy integrated Delphi- FAHP- FPROMETHEE methodology proposed in this paper includes the definition of subjective judgments, a

622 sensitivity analysis was performed in order to investigate how changing the weights of the 623 criteria affects the ranking of renewable alternatives.

The functionality of weight stability intervals on Visual PROMETHEE software [71] was used in order to perform the sensitivity analysis. The weight stability intervals indicate the range in term of percentage for each criterion, where changing the criterion weight would not affect the

627 global ranking of renewable energy alternatives.

628 Table 8 indicates the criteria weight stability intervals in term of percentage for the group decision. Accordingly, varying the weight of both $\mathrm{CO}_{2}$ reduction and energy production within the interval $[0 \%, 100 \%]$ would not affect the global ranking of renewable energy alternatives.

631 Likewise, varying the weight of usability within the interval [10\%, 100\%] would not affect the 
global ranking. Similarly, modifying the weights of investment cost and payback period respectively within the intervals $[5 \%, 43 \%]$ and $[0 \%, 31 \%]$ would not affect the global ranking. The sensitivity analysis indicates that significant variations in criteria weights would not influence the global ranking of renewable energy alternatives; this demonstrates that the fuzzy integrated Delphi- FAHP- FPROMETHEE methodology proposed in this paper is robust with respect to the different preferences.

Table 8: Weight stability intervals of the criteria

\begin{tabular}{|l|l|l|}
\hline \multirow{2}{*}{ Criteria } & \multicolumn{2}{|l|}{ \% weight stability intervals } \\
\cline { 2 - 3 } & Min & Max \\
\hline Investment cost & 5 & 43 \\
\hline Payback period & 0 & 31 \\
\hline Energy production & 0 & 100 \\
\hline $\mathrm{CO}_{2}$ reduction & 0 & 100 \\
\hline Usability & 10 & 100 \\
\hline
\end{tabular}

\section{Discussion}

Most applications of MCDA methods reported in the literature focus on the evaluation of renewable energy alternatives for electricity generation at a global, national, or regional scale [10-16, 28, 30-36]. However, there are limited uses of MCDA methods for the evaluation of renewable energy alternatives for electricity generation at the scale of a single residential building [17, 37-39], which opens a research demand. The originality of this paper is to propose a new fuzzy integrated multi-criteria decision-making method for the evaluation of renewable energy alternatives for electricity generation in a single residential building. The suggested fuzzy integrated method combines the Delphi method, the FAHP method, and the FPROMETHEE methods, which is completely innovative even in the literature of multi-criteria decision-making. The integration of these methods allows them to be complementary, with one method addressing the limitations of the other method. The paper presented a case study in 

and practical requirements. Table 9 presents a summary of the findings.

Table 9: Summary of the findings.

\begin{tabular}{|c|c|}
\hline $\begin{array}{l}\text { Parameters of } \\
\text { comparison }\end{array}$ & $\begin{array}{l}\text { Comparison of the results obtained from the application of the } \\
\text { proposed methodology with the available literature }\end{array}$ \\
\hline $\begin{array}{l}\text { Determination of } \\
\text { renewable energy } \\
\text { alternatives and } \\
\text { evaluation criteria }\end{array}$ & $\begin{array}{l}\text { The combination of Delphi method with experts and decision makers } \\
\text { as well as questionnaires with residents allowed the identification of } \\
\text { priorities and the selection of a limited number of alternatives and } \\
\text { criteria ( } 5 \text { alternatives and } 5 \text { criteria). This provides the proposed } \\
\text { method greater agility in the decision process compared to available } \\
\text { methods in the literature [14, 32,96] where a large number of criteria } \\
\text { considered have undermined their performance. }\end{array}$ \\
\hline $\begin{array}{l}\text { Determination of } \\
\text { weights }\end{array}$ & $\begin{array}{l}\text { The FAHP method is suitable to deal with imprecision in the } \\
\text { judgments of both experts and decision-makers, which agree with } \\
\text { Junior et al. [98]. } \\
\text { The findings of this research indicate that reducing the number of } \\
\text { pairwise comparisons through questionnaires helped not to } \\
\text { compromise human judgment and its consistency. This is in contrast } \\
\text { with available fuzzy methods in the literature [17, 12, 32, 34] where } \\
\text { considerable amount of judgments due to a large number of criteria } \\
\text { considered have increased the probability that the participants } \\
\text { introduce incorrect data. } \\
\text { With only five criteria, the use of the FAHP method was perfectly } \\
\text { viable as indicated in Saaty [43]. } \\
\text { The weights of the criteria obtained through FAHP were coherent, } \\
\text { consistent, and precise. This is in agreement with Kabir and Sumi [45]. } \\
\text { The FAHP method requires complex computations that can make it } \\
\text { difficult to use that agree with Junior et al. [98]. }\end{array}$ \\
\hline $\begin{array}{l}\text { Aggregation } \\
\text { approach }\end{array}$ & $\begin{array}{l}\text { FPROMETHEE method allowed dealing with vagueness and } \\
\text { approximations in the evaluations of renewable energy alternatives. } \\
\text { This is in contrast with other methods in the literature [10,11,13- } \\
16,29,29,30,31,33,35,36,38,39] \text {, which cannot prevent the loss of } \\
\text { valuable evaluation data. } \\
\text { The best alternative was } 2 \text { Axis tracking photovoltaic system despite } \\
\text { the fact that it has weak features in the most important criteria, which } \\
\text { is the investment cost. The findings indicate that the proposed } \\
\text { methodology does not allow the compensation between criteria. This is } \\
\text { in contrast with other fuzzy methods in the literature [12, 32, 34, 17] }\end{array}$ \\
\hline
\end{tabular}




\begin{tabular}{|l|l|}
\hline & $\begin{array}{l}\text { that can deal with vagueness but allow the compensation between } \\
\text { criteria, which could lead to biased outcomes. }\end{array}$ \\
\hline $\begin{array}{l}\text { Stability of the } \\
\text { proposed method }\end{array}$ & $\begin{array}{l}\text { The results of the sensitivity analysis indicate that the proposed method } \\
\text { is stable regarding the different preferences. This is in contrast with the } \\
\text { outcomes of other methods in the literature [34], which are strongly } \\
\text { influenced by decision makers' preferences. }\end{array}$ \\
\hline $\begin{array}{l}\text { Practical } \\
\text { requirements }\end{array}$ & $\begin{array}{l}\text { When the number of criteria is more than 7, the proposed methodology } \\
\text { can be time-consuming and difficult for decision-makers to obtain a } \\
\text { clear view of the decision problem as indicated in Macharis [44]. }\end{array}$ \\
\hline
\end{tabular}

659

Determination of evaluation criteria and renewable energy alternatives:

661

Most of MCDA approaches proposed for the evaluation of renewable energy alternatives for electricity generation used an assessment of the available literature in order to determinate the evaluation criteria $[14,32,96]$ while few approaches used open discussions and questionnaires [17]. A strong aspect of the proposed method compared to other methods available in the literature is its capability to combine Delphi method with experts and decision makers as well as questionnaires with residents. The results of the case study indicate that this combination allows the identification of priorities and the selection of a limited number of renewable energy alternatives and criteria (5 alternatives and 5 criteria) on a participatory base. The Delphi technique was practical to improve the communication among experts and decision-makers in order to select a set of renewable energy alternatives for electricity generation, as well as a set of preliminary evaluation criteria as shown in tables 3 and 5. This is in agreement with Seddiki et al. [40]. Moreover, the results show that the use of the questionnaires with the residents significantly decreased the number of criteria (from 9 criteria to 5 criteria see tables 3 and 5). This provides the proposed method greater agility in the decision process compared to available methods in the literature [14, 32, 96] where a large number of criteria considered have undermined their performance.

From the group decision perspective, the relevant criteria were the investment cost, the payback period, the energy production, $\mathrm{CO}_{2}$ reduction, and the usability. The selected criteria in this paper fulfilled the general requirements listed by Keeney et al. [42]. Accordingly, they 
680

681

682

683

684

685

686

687

688

689

690

691

692

693

694

695

696

697

698

699

700

701

702

703

were considered as appropriate. The residents did not include social criteria and technical

criteria, the causes might be the complexity of data collection and time requirements.

\section{Determination of weights}

As indicated in Balin el al. [97], in renewable energy decision-making problems, the preferences of experts and decision-makers are generally uncertain. Most of MCDA methods proposed in the literature do not consider this vagueness and imprecision while only few fuzzy approaches have been proposed in the literature [17, 12, 32, 34].

In this paper, the FAHP method as proposed by Gupta et al [53] has been implemented in order to determinate criteria weights taking into account the uncertainties in the judgments of experts and decision-makers since FPROMETHEE method does not provide guidelines for weight's elicitations. In order to deal with uncertain data, the FAHP uses pairwise comparisons by means of comparative linguistic variables. The results indicate that the FAHP method is suitable to deal with imprecision in the judgments of both experts and decision-makers, which agree with Junior et al. [98]. The findings of this research indicate that reducing the number of pairwise comparisons through questionnaires helped not to compromise human judgment and its consistency. This is in contrast with available fuzzy methods in the literature [17, 12, 32, 34] where considerable amount of judgments due to a large number of criteria considered have increased the probability that the participants introduce incorrect data. With five criteria, the use of the Fuzzy AHP method was perfectly viable as indicated in Saaty [43]. The results show that the weights of the criteria obtained through FAHP were coherent, consistent, and precise. This is in agreement with Kabir and Sumi [45]. However, according to the case study presented in this paper, the FAHP method requires complex computations that can make it difficult to use, which agree with Junior et al. [98].

Aggregation approach 
Most of MCDA methods applied for the evaluation of renewable energy alternatives use the complete aggregation approach [10-14,28-30,32-35], while only few methods use the partial aggregation PROMETHEE [15,16,31,36,39]. The complete aggregation approach presents the disadvantage to allow the compensation of low score in criteria with good results on several other criteria while the partial aggregation approach does not allow the compensation between criteria [40]. To the best knowledge of the authors, this work adds a significant contribution by implementing the partial aggregation FPROMETHEE for the evaluation of renewable energy alternatives for electricity generation in a single residential building. The results of the case study indicate that FPROMETHEE method suited well for this kind of problem as it takes into consideration vagueness and approximations in the evaluations of different experts and decision makers and allows to determinate the best renewable energy alternatives for electricity generation. This is in contrast with other methods in the literature $[10,11,13-$ $16,29,29,30,31,33,35,36,38,39]$, which cannot prevent the loss of valuable evaluation data. The best alternative was 2 Axis tracking photovoltaic system despite the fact that it has weak features in the most important criteria which is the investment cost. This indicates that the best renewable energy alternative is not the alternative that has the best features in the criteria with the highest weight, but the alternative that represents the best compromise, which agree with Macharis et al. [44]. The findings indicate that a strong aspect of the proposed method is to use the partial aggregation approach, which does not allow the compensation between criteria. This is in contrast with other fuzzy methods available in the literature [12, 17, 32, 34] that can deal with vagueness but allow the compensation between criteria, which could lead to biased outcomes.

Furthermore, another point of the proposed method compared to the available methods in the literature is to provide specific guidelines (step 11 of the methodology) in order to deal with possible conflicts among decision makers. 
Stability of the proposed method:

The validity of the results was assessed through sensitivity analysis. The results of the sensitivity analysis indicate that the fuzzy integrated Delphi- FAHP- FPROMETHEE methodology proposed in this paper is stable regarding the different preferences. This is in contrast with the outcomes of other methods in the literature [34], which are strongly influenced by decision makers' preferences. Ultimately, the participants confirmed the validity of the method as they have all agreed on the selected renewable energy alternative. One should notice that the selected renewable energy alternatives and criteria as well as the criteria weights' and the ranking of the alternatives are specific to this case study and are not to be considered applicable to other buildings. The method proposed in this paper is universal. It is not limited to the selection of the best renewable energy alternative for electricity generation in residential buildings.

\section{Practical requirement:}

The proposed methodology presents several limitations. When the number of the criteria selected through Delphi method and questionnaires is more than 7 , the method can be timeconsuming and difficult for decision-makers to obtain a clear view of the decision problem as indicated in Macharis [44]. Furthermore, the application of the proposed method requires a complete support from residents, project stakeholders as well as the participation of a specific consultant with necessary skills in decision making which is not often possible.

\section{Conclusion}

The selection of the best renewable energy alternative for electricity generation in a single residential building is a complex decision problem involving a large number of alternatives and criteria, different stakeholder's, as well as uncertain, inaccurate and subjective data.

The multiple-criteria decision analysis is a practical tool for this type of problem, it supports decision-makers to select the best alternative. This paper has an innovative value due to the 
proposal of new integrated fuzzy multi-criteria group decision-making method for the selection of the best renewable energy alternatives for electricity generation in a single residential building. The proposed method combines Delphi method, questionnaire, FAHP method and FPROMETHEE methods. The application of the proposed method to a real case study showed encouraging results as it was possible to select the best renewable energy alternative. The proposed integrated method helps to formulate the problem and is particularly effective in handling uncertain data. Delphi technique was practical to improve the communication among experts and decision-makers in order to select a set of renewable energy alternatives for electricity generation, as well as a set of preliminary evaluation criteria. The questionnaire with the residents significantly decreases the number of criteria which reduces the probability that the participants introduce incorrect data and provides the proposed method greater agility in the decision process. The FAHP method provides specific guidelines for the determination of the criteria weight's and allows to take into account the uncertainties in expert's judgments. The results of FAHP show that the weights of the criteria obtained through FAHP were coherent, consistent, and precise. The FPROMETHEE method is effective to determinate the best renewable energy alternatives for electricity generation. The FPROMETHEE method suited well for this kind of problem as it can prevent the loss of valuable evaluation data and takes into consideration vagueness and approximations in the evaluations of different experts and decision-makers. The sensitivity analysis reveals that the proposed method is robust with respect to the different decision maker's preferences. For future works, in addition to the application of the proposed methodology to other types of energy problems, similar studies can be conducted using different fuzzy multi-criteria decision-making techniques such as fuzzy ELECTRE or fuzzy TOPSIS for comparative purposes.

\section{References}

[1] Pablo-Romero MdP, Pozo-Barajas R, Yñiguez R. Global changes in residential energy consumption. Energy Policy. 2017;101:342-352. 
[2] IEA. Statistics Report. Paris (France). International Energy Agency, 2016. consumption, $\mathrm{CO}_{2}$ emissions and policy in the residential sector (with an overview of the top [4] Kumar A, Sah B, Singh AR, Deng Y, He X, Kumar P, Bansal, R. C. A review of multi criteria decision making (MCDM) towards sustainable renewable energy development. Renewable and sustainable energy reviews. 2017;69:596-609.

[5] Adib R, Murdock H, Appavou F, Brown A, Epp B, Leidreiter A. Renewables 2016 Global Status Report. Renewable Energy Policy Network for the 21st century (REN21).

[6] Vullo P, Passera A, Lollini R. Implementation of a multi-criteria and performance-based procurement procedure for energy retrofitting of facades during early design. Sustainable Cities and Society. 2018;36:363-377.

[7] Del Rio P. Analysing future trends of renewable electricity in the EU in a low-carbon context. Renewable and sustainable energy reviews. 2011;15(5):2520-2533.

[8] Gupta P, Anand S, Gupta H. Developing a roadmap to overcome barriers to energy efficiency in buildings using best worst method. Sustainable Cities and Society. 2017;31:244259.

[9] Yaqoot M, Diwan P, Kandpal TC. Review of barriers to the dissemination of decentralized renewable energy systems. Renewable and sustainable energy reviews. 2016;58:477-490.

[10] Maxim A. Sustainability assessment of electricity generation technologies using weighted multi-criteria decision analysis. Energy Policy. 2014;65:284-297.

[11] Ahmad S, Tahar RM. Selection of renewable energy sources for sustainable development of electricity generation system using analytic hierarchy process: A case of Malaysia.

Renewable Energy. 2014;63:458-466.

[12] Kaya T, Kahraman C. Multicriteria renewable energy planning using an integrated fuzzy VIKOR \& AHP methodology: The case of Istanbul. Energy. 2010;35(6):2517-2527.

[13] Štreimikienė D, Šliogerienė J, Turskis Z. Multi-criteria analysis of electricity generation technologies in Lithuania. Renewable Energy. 2016;85:148-156.

[14] Al Garni H, Kassem A, Awasthi A, Komljenovic D, Al-Haddad K. A multicriteria decision making approach for evaluating renewable power generation sources in Saudi Arabia. Sustainable Energy Technologies and Assessments. 2016;16:137-150.

[15] Diakoulaki D, Karangelis F. Multi-criteria decision analysis and cost-benefit analysis of alternative scenarios for the power generation sector in Greece. Renewable and sustainable energy reviews. 2007;11(4):716-727.

[16] Barragán A, Arias P, Terrados J. Renewable Energy Generation Technologies on Urban Scale. Renewable Energy and Power Quality Journal. 2017;15.

[17] Kontu K, Rinne S, Olkkonen V, Lahdelma R, Salminen P. Multicriteria evaluation of heating choices for a new sustainable residential area. Energy and Buildings. 2015;93:169179.

[18] Scarpa R, Willis K. Willingness-to-pay for renewable energy: Primary and discretionary choice of British households' for micro-generation technologies. Energy Economics. 2010;32(1):129-136.

[19] Štreimikienė D, Baležentis A. Assessment of willingness to pay for renewables in Lithuanian households. Clean Technologies and Environmental Policy. 2015;17(2):515-531. [20] Tampakis S, Arabatzis G, Tsantopoulos G, Rerras I. Citizens’ views on electricity use, savings and production from renewable energy sources: A case study from a Greek island. Renewable and sustainable energy reviews. 2017;79:39-49. [21] Suganthi L, Iniyan S, Samuel AA. Applications of fuzzy logic in renewable energy systems-a review. Renewable and sustainable energy reviews. 2015;48:585-607. 
[22] Mamlook R, Akash BA, Mohsen MS. A neuro-fuzzy program approach for evaluating electric power generation systems. Energy. 2001;26(6):619-632.

[23] Tasri A, Susilawati A. Selection among renewable energy alternatives based on a fuzzy analytic hierarchy process in Indonesia. Sustainable Energy Technologies and Assessments. 2014;7:34-44.

[24] Ren J, Sovacool BK. Enhancing China’s energy security: Determining influential factors and effective strategic measures. Energy Conversion and Management. 2014;88:589-597. [25] Cai Y, Huang G, Tan Q, Yang Z. An integrated approach for climate-change impact analysis and adaptation planning under multi-level uncertainties. Part I: Methodology. Renewable and sustainable energy reviews. 2011;15(6):2779-2790.

[26] Wang J-J, Jing Y-Y, Zhang C-F, Zhao J-H. Review on multi-criteria decision analysis aid in sustainable energy decision-making. Renewable \& sustainable energy reviews. 2009;13(9):2263-2278.

[27] Mardani A, Jusoh A, Zavadskas EK. Fuzzy multiple criteria decision-making techniques and applications - Two decades review from 1994 to 2014. Expert Systems with Applications. 2015;42(8):4126-4148.

[28] Palmas C, Abis E, von Haaren C, Lovett A. Renewables in residential development: an integrated GIS-based multicriteria approach for decentralized micro-renewable energy production in new settlement development: a case study of the eastern metropolitan area of Cagliari, Sardinia, Italy. Energy, Sustainability and Society. 2012;2(1):10.

[29] Önüt S, Tuzkaya UR, Saadet N. Multiple criteria evaluation of current energy resources for Turkish manufacturing industry. Energy Conversion and Management. 2008;49(6):14801492.

[30] Talukdar MA, Rahman H, Sarker PC. Multi criteria Decision Analysis Algorithm based Optimal Selection of PV Panel for Grid-tie PV Electricity Generation System in context of Dhaka, Bangladesh. Life. 2017;5(2).

[31] Strantzali E, Aravossis K, Livanos GA. Evaluation of future sustainable electricity generation alternatives: The case of a Greek island. Renewable and sustainable energy reviews. 2017;76:775-787.

[32] Çelikbilek Y, Tüysüz F. An integrated grey based multi-criteria decision making approach for the evaluation of renewable energy sources. Energy. 2016;115:1246-1258. [33] Kausika B, Dolla O, Van Sark W. Assessment of policy based residential solar PV potential using GIS-based multicriteria decision analysis: A case study of Apeldoorn, The Netherlands. Energy Procedia. 2017;134:110-120.

[34] Jung N, Moula ME, Fang T, Hamdy M, Lahdelma R. Social acceptance of renewable energy technologies for buildings in the Helsinki Metropolitan Area of Finland. Renewable Energy. 2016;99:813-824.

[35] Rojas-Zerpa JC, Yusta JM. Application of multicriteria decision methods for electric supply planning in rural and remote areas. Renewable and sustainable energy reviews. 2015;52:557-571.

[36] Wu Y, Wang Y, Chen K, Xu C, Li L. Social sustainability assessment of small hydropower with hesitant PROMETHEE method. Sustainable Cities and Society. 2017;35:522-537.

[37] Lu Y, Wang S, Zhao Y, Yan C. Renewable energy system optimization of low/zero energy buildings using single-objective and multi-objective optimization methods. Energy and Buildings. 2015;89:61-75.

[38] Catalina T, Virgone J, Blanco E. Multi-source energy systems analysis using a multicriteria decision aid methodology. Renewable Energy. 2011;36(8):2245-2252.

[39] Ren H, Gao W, Zhou W, Nakagami Ki. Multi-criteria evaluation for the optimal adoption of distributed residential energy systems in Japan. Energy Policy. 2009;37(12):5484-5493. 
[40] Seddiki M, Anouche K, Bennadji A, Boateng P. A multi-criteria group decision-making method for the thermal renovation of masonry buildings: The case of Algeria. Energy and Buildings. 2016;129:471-483.

[41] Mousavi SM, Tavakkoli-Moghaddam R, Heydar M, Ebrahimnejad S. Multi-criteria decision making for plant location selection: an integrated Delphi-AHP-PROMETHEE methodology. Arabian Journal for Science and Engineering. 2013;38(5):1255-1268. [42] Keeney S, Hasson F, McKenna H. Consulting the oracle: ten lessons from using the Delphi technique in nursing research. Journal of advanced nursing. 2006;53(2):205-212. [43] Saaty TL. Decision making for leaders: the analytical hierarchy process for decisions in a complex world. Wadsworth,Belmont.: Lifetime Learning Publications; 1982.

[44] Macharis C, Springael J, De Brucker K, Verbeke A. PROMETHEE and AHP: The design of operational synergies in multicriteria analysis.: Strengthening PROMETHEE with ideas of AHP. Management of the Future MCDA: Dynamic and Ethical Contributions. 2004;153(2):307-317.

[45] Kabir G, Sumi R. Power substation location selection using fuzzy analytic hierarchy process and PROMETHEE: A case study from Bangladesh. Energy. 2014;72(Journal Article):717-730.

[46] Yang C-C, Chen B-S. Key quality performance evaluation using fuzzy AHP. Journal of the Chinese Institute of Industrial Engineers. 2004;21(6):543-50. [47] Zadeh L. A., 1978. Fuzzy Sets as a basis for a theory of Possibility. Fuzzy Sets and Systems. 1978;1(1):3-28.

[48] Taha Z, Rostam S. A hybrid fuzzy AHP-PROMETHEE decision support system for machine tool selection in flexible manufacturing cell. Journal of Intelligent Manufacturing. 2012;23(6):2137-2149.

[49] Van Laarhoven PJM, Pedrycz W. A fuzzy extension of Saaty's priority theory. Fuzzy Sets and Systems. 1983;11(1-3):229-241.

[50] Buckley JJ. Fuzzy hierarchical analysis. Fuzzy Sets and Systems. 1985;17(3):233-247. [51] Chang D-Y. Applications of the extent analysis method on fuzzy AHP. European Journal of Operational Research. 1996;95(3):649-655.

[52] Seddiki M, Anouche K, Bennadji A. Integrated FAHP-FPROMETHEE for thermal insulation of masonry buildings. Facilities. 2018;36(3/4):195-211.

[53] Gupta R, Sachdeva A, Bhardwaj A. Selection of logistic service provider using fuzzy PROMETHEE for a cement industry. Journal of Manufacturing Technology Management. 2012;23(7):899-921.

[54] Seddiki M, Anouche K, Bennadji A. An integrated Delphi-FAHP-PROMETHEE for the thermal renovation of masonry buildings in Algeria. Proceedings of the 5th international conference on heritage and sustainable development, Lisbon, Portugal. Barcelos: Green Lines Institute. 2016;171-180.

[55] Bilsel RU, Büyüközkan G, Ruan D. A fuzzy preference-ranking model for a quality evaluation of hospital web sites. International Journal of Intelligent Systems. 2006;21(11):1181-1197.

[56] Brans J. The engineering of decision: Elaboration instruments of decision support method PROMETHEE. Laval University, Quebec, Canada. Laval University, Quebec Canada; 1982.

[57] Brans J-P, Mareschal B. The PROMCALC \& GAIA decision support system for multicriteria decision aid. Decision Support Systems. 1994;12(4-5):297-310. [58] Brans JP. PROMETHEE V: MCDM problems with segmentation constraints. Information systems and operational research. 1992;30(2):85. 
[59] Macharis C, Brans JP, Mareschal B. The GDSS PROMETHEE procedure a PROMETHEE-GAIA based procedure for group decision support. Journal of decision systems. 1998;7(Journal Article):283-307.

[60] Durucasu H, Aytekin A, Saraç B, Orakçı E. Current Application Fields of ELECTRE and PROMETHEE: A Literature Review. Alphanumeric Journal. 2017;5(2):229-270.

[61] Goumas M, Lygerou V. An extension of the PROMETHEE method for decision making in fuzzy environment: Ranking of alternative energy exploitation projects. European Journal of Operational Research. 2000;123(3):606-613.

[62] Geldermann J, Spengler T, Rentz O. Fuzzy outranking for environmental assessment. Case study: iron and steel making industry. Fuzzy Sets and Systems. 2000;115(1):45-65.

[63] Chou W-C, Lin W-T, Lin C-Y. Application of fuzzy theory and PROMETHEE technique to evaluate suitable ecotechnology method: A case study in Shihmen Reservoir Watershed, Taiwan. Ecological Engineering. 2007;31(4):269-280.

[64] Motlagh SMH, Behzadian M, Ignatius J, Goh M, Sepehri MM, Hua TK. Fuzzy PROMETHEE GDSS for technical requirements ranking in HOQ. The International Journal of Advanced Manufacturing Technology. 2015;76(9-12):1993-2002.

[65] Peng Y, Kou G, Li J. A fuzzy PROMETHEE approach for mining customer reviews in chinese. Arabian Journal for Science and Engineering. 2014;39(6):5245-5252.

[66] Ozsahina DU, Uzuna B, Musaa MS, Helwana A, Wilsona CN, Veysel F, et al. Evaluating Cancer Treatment Alternatives using Fuzzy PROMETHEE Method. International journal of advanced computer science and applications. 2017;8(10):177-182.

[67] Çelik P, Gökkisa AC. Fuzzy AHP-fuzzy PROMETHEE approach in evaluation of eservice quality: Case of airline web sites. Journal of International Social Research. 2017;10(52).

[68] Brans JP, Vincke P, Mareschal B. How to select and how to rank projects: The PROMETHEE method. Mathematical Programming Multiple Criteria Decision Making. 1986;24(2):228-238.

[69] Rezaie B, Esmailzadeh E, Dincer I. Renewable energy options for buildings: case studies. Energy and Buildings. 2011;43(1):56-65.

[70] Rodrigues M, Valdez M, Coelho D. Renewable energy in residential buildings: Analysis of different micro-generation systems. International Conference on Renewable Energies and Power Quality,(ICREPQ'I2), Santiago de Compostela, Spain; 2012.

[71] VP solutions , Mareschal B. The Visual PROMETHEE Academic Edition. 2012. [72] Chinese D, Nardin G, Saro O. Multi-criteria analysis for the selection of space heating systems in an industrial building. Energy. 2011;36(1):556-65.

[73] Golić K, Kosorić V, Furundžić AK. General model of solar water heating system integration in residential building refurbishment—Potential energy savings and environmental impact. Renewable and sustainable energy reviews. 2011;15(3):1533-44.

[74] Alanne K. Selection of renovation actions using multi-criteria "knapsack" model. Automation in Construction. 2004;13(3):377-91. [75] Kaklauskas A, Zavadskas EK, Raslanas S. Multivariant design and multiple criteria analysis of building refurbishments. Energy and Buildings. 2005;37(4):361-72.

[76] Rosenfeld Y, Shohet IM. Decision support model for semi-automated selection of renovation alternatives. Automation in Construction. 1999;8(4):503-10.

[77] Diakaki C, Grigoroudis E, Kabelis N, Kolokotsa D, Kalaitzakis K, Stavrakakis G. A multi-objective decision model for the improvement of energy efficiency in buildings. The 3rd International Conference on Sustainable Energy and Environmental Protection, SEEP 2009. 2010;35(12):5483-96. 
[78] Juan Y-K, Gao P, Wang J. A hybrid decision support system for sustainable office building renovation and energy performance improvement. Energy and Buildings. 2010;42(3):290-7. [79] Zagorskas J, Zavadskas E, Turskis Z, Burinskiene M, Blumberga A, Blumberga D. Thermal insulation alternatives of historic brick buildings in Baltic Sea Region. Energy and Buildings. 2014;78:35-42.

[80] Akadiri PO, Olomolaiye PO, Chinyio EA. Multi-criteria evaluation model for the selection of sustainable materials for building projects. Automation in Construction. 2013;30:113-25.

[81] Chen Y, Okudan GE, Riley DR. Decision support for construction method selection in concrete buildings: Prefabrication adoption and optimization. Automation in Construction. 2010;19(6):665-75.

[82] Šaparauskas J, Kazimieras Zavadskas E, Turskis Z. Selection of facade's alternatives of commercial and public buildings based on multiple criteria. International Journal of Strategic Property Management. 2011;15(2):189-203.

[83] Tam C, Tong TK, Wong Y. Selection of concrete pump using the superiority and inferiority ranking method. Journal of construction engineering and management. 2004;130(6):827-34.

[84] Stambouli AB. Algerian renewable energy assessment: The challenge of sustainability. Energy Policy. 2011;39(8):4507-4519.

[85] Surface meteorology and solar energy. NASA renewable energy resource Website, https://power.larc.nasa.gov/data-access-viewer/;2018 [accessed 01 February 2018]. [86] Stambouli AB, Khiat Z, Flazi S, Kitamura Y. A review on the renewable energy development in Algeria: Current perspective, energy scenario and sustainability issues. Renewable and sustainable energy reviews. 2012;16(7):4445-4460. [87] Himri Y, Malik AS, Stambouli AB, Himri S, Draoui B. Review and use of the Algerian renewable energy for sustainable development. Renewable and sustainable energy reviews. 2009;13(6):1584-1591.

[88] Alfonso D, Perpiñá C, Pérez-Navarro A, Peñalvo E, Vargas C, Cárdenas R. Methodology for optimization of distributed biomass resources evaluation, management and final energy use. Biomass and Bioenergy. 2009;33(8):1070-1079.

[89] Garba A, Kishk M, Moore DR. Models for Sustainable Electricity Provision in Rural Areas Using Renewable Energy Technologies-Nigeria Case Study. Building Information Modelling, Building Performance, Design and Smart Construction: Springer; 2017;191-205. [90] Bocci E, Sisinni M, Moneti M, Vecchione L, Di Carlo A, Villarini M. State of art of small scale biomass gasification power systems: a review of the different typologies. Energy Procedia. 2014;45:247-256.

[91] Salem Z, Lebik H, Cherafa W, Allia K. Valorisation of olive pits using biological denitrification. Desalination. 2007;204(1-3):72-78.

[92] Sharif MR, Rahman MN, Chowdhury MHR, Shoeb MA, editors. Designing of an optimized building integrated hybrid energy generation system. Development in the in Renewable Energy Technology (ICDRET), 2016 4th International Conference on the; 2016: IEEE.

[93] Energy H. HOMER pro version 3.7 user manual. no August. 2016:416. [94] Mohammed M, Aziz A, Alwaeli AH, Kazem HA. Optimal sizing of photovoltaic systems using HOMER for Sohar, Oman. International Journal of Renewable Energy Research (IJRER). 2013;3(3):470-475. 
1023 [95] Bensaad H. Les émissions du dioxyde de carbone en Algérie. Le Soir d'Algérie,

1024 https://www.lesoirdalgerie.com/articles/2014/10/13/article.php?sid=169628\&cid=41; 2014

1025 [accessed 13 October 2014].

1026 [96] Zhang S, Huang P, Sun Y. A multi-criterion renewable energy system design optimization for net zero energy buildings under uncertainties. Energy. 2016;94:654-665.

1028 [97] Balin A, Baraçli H. A fuzzy multi-criteria decision making methodology based upon the 1029 interval type-2 fuzzy sets for evaluating renewable energy alternatives in Turkey.

1030 Technological and economic development of economy. 2017;23(5):742-763.

1031 [98] Junior FRL, Osiro L, Carpinetti LCR. A comparison between Fuzzy AHP and Fuzzy TOPSIS methods to supplier selection. Applied Soft Computing. 2014;21:194-209. 